University of Rhode Island

DigitalCommons@URI

Open Access Master's Theses

1988

\title{
The Regulation of Underground Storage Tanks
}

Mary Katherine Maxwell

University of Rhode Island

Follow this and additional works at: https://digitalcommons.uri.edu/theses

\section{Recommended Citation}

Maxwell, Mary Katherine, "The Regulation of Underground Storage Tanks" (1988). Open Access Master's Theses. Paper 729.

https://digitalcommons.uri.edu/theses/729

This Thesis is brought to you for free and open access by DigitalCommons@URI. It has been accepted for inclusion in Open Access Master's Theses by an authorized administrator of DigitalCommons@URI. For more information, please contact digitalcommons-group@uri.edu. 
THE REGULATION OF UNDERGROUND STORAGE TANKS

BY

MARY KATHERINE MAXWELL

A RESEARCH PROJECT SUBMITTED IN

PARTIAL FULFILLMENT OF THE REQUIREMENTS

FOR THE DEGREE AND MASTER OF

COMMUNITY PLANNING

UNIVERSITY OF RHODE ISLAND

1988 
MASTER OF CUMMUNITY PLANNING

RESEARCH PROJECT

$\mathrm{OF}$

MARY KATHERINE MAXWELL

Approved:

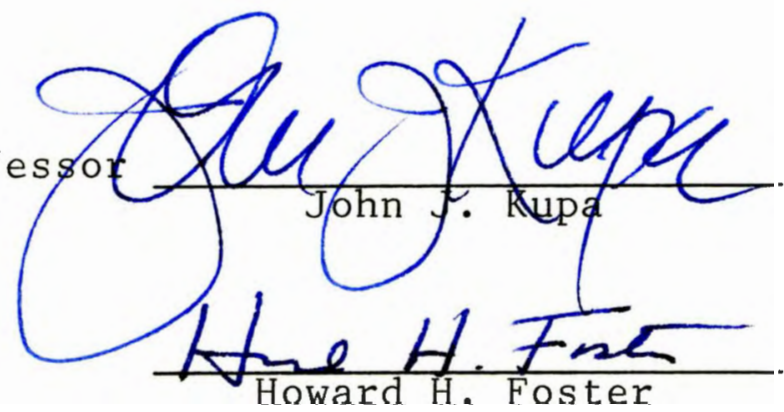




\section{ABSTRACT}

The components of gasoline are among the most toxic substances common in our environment. Yet because petroleum products are so ubiquitous and essential to the economic well being of our society, the hazards associated with exposure to these toxics have often been overlooked.

Recently, evidence of widespread groundwater pollution due to leaking underground storage of petroleum and other hazardous substances has come to light. Because dependence on groundwater for drinking water supplies is so great and because this dependence is expected to grow in the future, the Environmental Protection Agency has proposed a regulatory scheme to control and manage the hazards associated with underground storage. Groundwater aquifers are extremely fragile and finite resources deserving federal protection. This paper will attempt to illuminate the nature and scope of the underground storage problem and explore the solutions the EPA proposed through their regulation program. of the state regulatory programs which exceed federal minimum requirements, the Rhode Island regulation plan will be analyzed as an especially sensitive and effective program which is likely to be emulated by other states with similar groundwater and tank conditions. Finally regulatory and non-regulatory measures which may be adopted by 
municipalities will be outlined along with enforcement procedures designed to ensure compliance and maximum protection of groundwater resources from pollution associated with underground storage of petroleum products and other hazardous substances. 


\section{ACKNOWLEDGEMENTS}

This work would not have been possible without the kind assistance and encouragement of Dr. John Kupa. His eloquence and his philosophy of strongly advocating for environmental concerns within a practical and realistic development framework has been an inspiration to me and will continue to be a source of guidance to me in my professional endeavors.

Within the Community Planning department, Dr. Howard Foster has continually displayed an unusual degree of patience, caring and flexibility which I often deeply appreciated.

To my husband, Hugh Maxwe11, I am more than grateful. He has been cheerful and unfailing in his emotional, financial and physical support through this project and throughout my years at C.P.A.D.

Finally, the students at C.P.A.D. provided an atmosphere of intense intellectual stimulation coupled with a memorable comaraderie. Their unflagging mutual cooperation taught me just how well groups can work together. They each contributed mightily to my development as a planner and as a human being.

$$
\text { M.K.M. }
$$




\section{PREFACE}

In response to perceived grave dangers to our nation's groundwaters, Congress directed the Environmental Protection Agency to develop a regulatory scheme to prevent the pollution of groundwater by leakage from underground storage tanks.

This paper will explain the scope and nature of the public health threat posed by leaking UST's in the first two chapters. The federal regulatory program proposed to control these hazards is outlined in Chapter III. The fourth chapter describes the state role in the regulation of underground storage with special emphasis on the Rhode Island regulations as an exemplary model of a state program. The final chapter outlines local initiatives that might further reduce the risk of groundwater pollution from underground storage in sensitive localities. 
TABLE OF CONTENTS

Chapter

I THE PROBLEMS WITH UNDERGROUND STORAGE TANKS • • 1

1.1. Background. . . . . . . . . . . . 1

1.2. Characteristics of Leaking Tanks. . . . 4

II GROUNDWATER HYDROLOGY . . . . . . . . . 9

2.1. Precipitation . . . . . . . . 9

2.2. Aquifers.............. . 10

2.3. Contamination of Groundwater. . . . . 14

III FEDERAL REGULATION FOR THE UNDERGROUND STORAGE OF PETROLEUM PRODUCTS . . . . . . . . . . 16

3.1. The Role of the Environmental

Protection Agency $\cdot . \cdot \cdot \cdot \cdot \cdot \cdot 16$

3.2. Exclusions to the Proposed Rule... . 17

3.3. Summary of Proposed Federal Rule. . . 17

3.4. Financial Assurances. . . . . . . 22

3.5. The Trust Fund for Leaking Underground Storage Tanks . . . . . . . 25

IV STATE AND LOCAL INITIATIVES FOR CONTROLLING

LEAKING UNDERGROUND STORAGE TANKS . . . . . . 28

4.1. Background. . . . . . . . . 28

4.2. State Regulatory Programs: The
Rhode Island Example... . . . 29

$\mathrm{V}$ COUNTY AND LOCAL UNDERGROUND STORAGE TANK INITIATIVES . . . . . . . . . . . . . 37

5.1. Background. . . . . . . . . . 37

5.2. Local Control of UST Hazards. . . . 39

5.3. The Community Tank Census ..... . 42

5.4. Enforcement.......... 44

APPENDIX A . . . . . . . . . . . . . 46

APPENDIX B . . . . . . . . . . . . . . 91

FOOTNOTES. . . . . . . . . . . . . . 104

BIBLIOGRAPHY . . . . . . . . . . . 106 


\section{LIST OF FIGURES}

Figure

1. Spills and Leaks Contaminating Groundwater. . . 3

2. The Hydrologic Cycle. . . . . . . . . . 11

3. Groundwater Aquifers. . . . . . . . . . 13

4. Typical Underground Storage Tank

Installation. . . . . . . . . . . 21

5. Leak Detection Methods. . . . . . . . . 32 
CHAPTER I

THE PROBLEMS WITH UNDERGROUND STORAGE TANKS

\subsection{Background}

Petroleum products and other toxic chemicals leaking from underground storage tanks are one of the most common causes of groundwater pollution. Reliance on groundwater is increasing in this country as surface water supplies are becoming less available. Municipal, state and federal records indicate that thousands of underground storage tanks (UST's) are currently leaking; many more are expected to develop leaks in the future. Because so many people in this country depend on groundwater, the federal government through legislation has sought to safeguard our nation's groundwater resources.

Congress attempted to begin a program to control leaking UST's when it added Subtitle 1 . to the Resource Conservation and Recovery Act. This law required the Environmental Protection Agency to develop regulations that would protect human beings and the environment from the threats that leaking UST's present.

For protection from fire and explosion risks, petroleum products are normally stored underground. The most typical storage facility is a retail gas station but 
petroleum products are also stored underground at convenience stores, motor pools, trucking fleet headquarters, airports, bus companies, and marinas. Petroleum is also stored in millions of small tanks located at homes and at small businesses across the country. Leaking petroleum or chemicals can pollute groundwater and such leaks may remain undetected for years. Treating the contaminated water is usually not feasible due to high costs. Treatment methods usually result in a water quality that is less than satisfactory. Also, during any groundwater restoration effort, an alternative source of drinking water must be provided.

Leaking tanks are not the only source of danger from stored petroleum. Spills and overfills account for a significant portion of the total groundwater pollutant load of petroleum (see Figure 1). Once on the ground, the product mass coats the soil and moves downward toward the groundwater where its soluble components mix with the water. The insoluble components usually float as a mass on top of the water.

Vapors can be inhaled by humans and are strongly suspected of causing serious illness. The chemical constituents of gasoline are extremely toxic; toxicological and limited human studies have found gasoline components to cause such health problems as anemia, nervous system disorders, kidney disease, cancer and lead poisoning. ${ }^{1}$ 


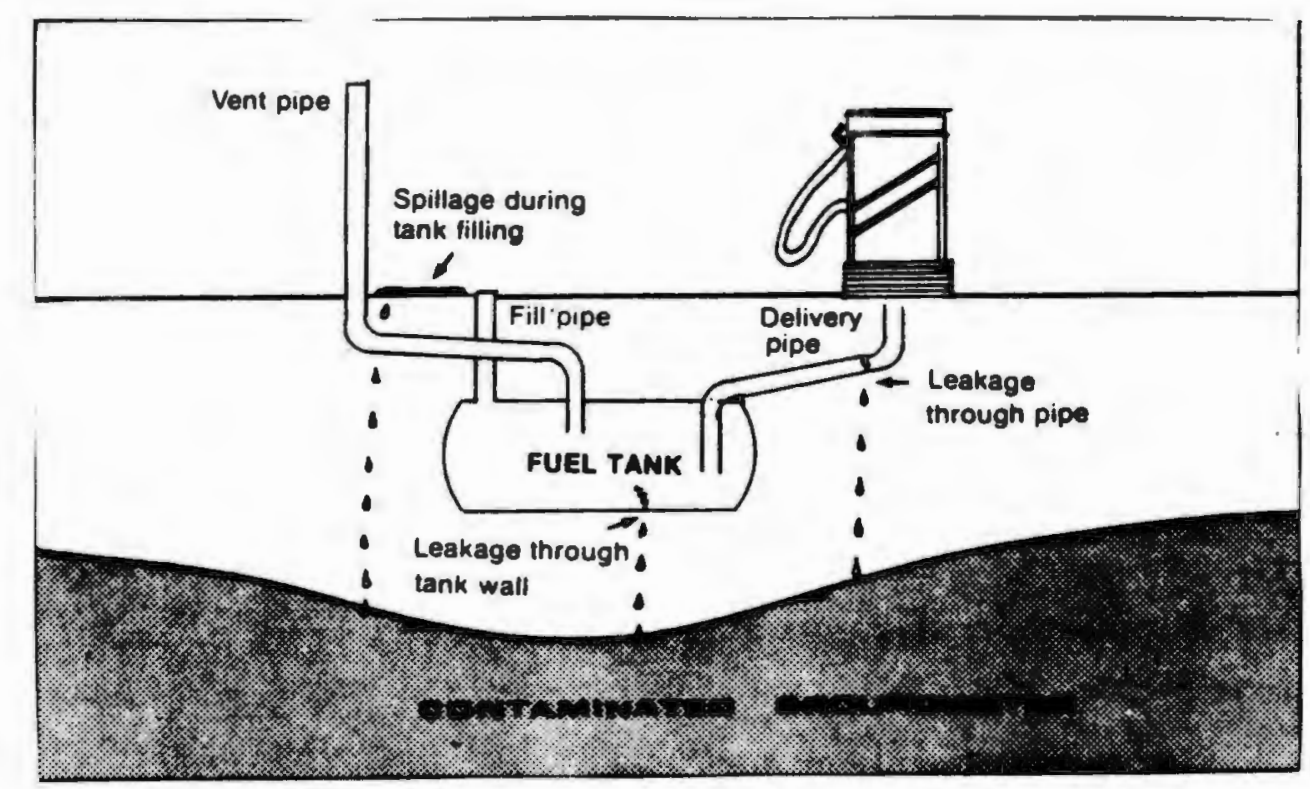

Figure 1.

Spills and Leaks Contaminating Groundwater

Petroleum products and other hazardous substances may be released into soil and eventually migrate to groundwater. This illustration shows that product may leak not only from the tank body itself but also from loose, broken or corroded pipes and fittings. Spills and overfills also account for a significant amount of free product release and eventual migration to the water table.

Source: Community Tank Census 
Ingestion through drinking water and ingestion through the inhalation of fumes are both considered extremely hazardous.

It must also be remembered that gasoline and other petroleum fuels are extremely volatile. Vapors from spills or groundwater leaks may migrate to invade basements, buildings and sewer pipes, spreading the threat of explosion and fire far and wide.

1.2. Characteristics of Leaking Tanks

Most of the tanks in the ground today are made of steel coated with asphalt but many steel tanks were installed bare thus exposing the metal to the corrosive effects of the surrounding soil. Fiberglass Reinforced Plastic (FRP) has also been used as an alternative tank material for about the last twenty years. It is not subject to corrosion as steel is but FRP is subject to structural failure and must be installed with extreme care. There are approximately 1.4 million tanks across the country that will be subject to regulation; according to EPA estimates about $89 \%$ are steel and the rest are made of FRP.

Prior to promulgating rules, in October of 1984 the EPA Office of Solid Waste undertook a study to obtain, document and analyze information concerning UST release incidents. Initial data collection was undertaken at the state level, with similar data later collected at the county and local level. The goals of the study were: 
- to identify the number of documented UST release incidents and the degree of documentation in the state files

- to analyze these data with respect to cause, impact, age, tank type and other relevant factors

- to determine whether any trends based on geographic distribution, tank age, materials stored, or other factors were apparent from the data. ${ }^{2}$

The various states surveyed had differing enforcement procedures so the final summary contains some inherent biases. However, the results substantially enhance our knowledge and understanding of circumstances surrounding UST leaks and also the results have been generally supported by subsequent studies.

The 1984 study found that there had been a continuous increase in the number of release incidents reported to state agencies annually from 1970 to 1984. While the increase may have been due to improved reporting procedures, an increase in the actual number of release incidents during this time cannot be ruled out.

The study analyzed information compiled for 12,444 UST release incidents in all 50 states. It was impossible to determine the percentage of tanks that actually leaked due to the irregularity of reporting procedures, but about $65 \%$ of the documented release incidents involved tanks at retail gas stations. This large percentage may have been due in part to the proximity of gas stations to 
population centers, which increases the likelihood of detection through sighting and smelling leaks, spills and vapor.

Only about $3 \%$ of the releases involved chemicals other than petroleum fuels and the majority of these releases occurred at chemical manufacturing facilities.

A full $95 \%$ of the reported release incidents occurred at operating facilities, as opposed to abandoned facilities. Larger quantities of released product were associated with operating facilities as well.

The median age of tank systems at the time of release was found to be 17 years. Piping leaks occurred most frequently around the age of 11 years. Poor installation practices are thought to significantly contribute to early pipe failures. Pipes usually have thinner walls than do tanks and therefore are more subject to corrosion leaks. Piping leaks accounted for a signficant portion of the total number of release incidents; it was concluded that any effective leak control program must address both tank and pipe leaks.

Overfills and spills accounted for $15 \%$ of all release incidents reported.

The study identified the most common documented causes of release incidents to be corrosion and structural failure, followed by improper installation and loosened pipe fittings. Structural failure was found to be most closely associated with the more significant release 
incidents, those involving 10,000 or more gallons of released product. Leaks associated with improper installation and loose fittings proved to be far more common in tank systems 10 years old or less.

Subsequent to the Summary of State Reports on Releases From Underground Storage Tanks cited above, the EPA completed a survey of underground motor fuel storage tanks conducted at 890 establishments covering 2,445 tanks. A selected subsample of this tank universe was tested for leaks (433 tanks). Major findings of this survey include the following:

- An estimated $35 \%$ of the tank systems failed the tightness test. This conclusion msut be interpreted with caution however because during the test, tanks were filled to a pressure slightly higher than that of normal operating levels.

- EPA could not identify any variable through statistical analysis, such as tank material or fuel type, that correlated strongly with test failure.

- At comparable ages, fiberglass and steel tanks showed no significant difference in the rate of test failure.

- Steel tanks showed little icnrease in the rate of failure with age in their first 20 years, but after 20 years failures increased. 
- The average age of tanks in the United States is 12 years old.

- Twenty-one percent of all tanks are installed partially or completely below the water table. 3

Leaking UST's are a major problem meriting Federal intervention. That intervention is focused upon requiring upgraded tank systems and protection through leak detection devices. It should be noted that major oil companies have already established tank upgrading programs as they are well aware of potential liability for damages and clean up costs. The tank upgrading programs have been in place for up to seven years in some cases. Spokespersons for both the American Petroleum Institute and the Steel Tank Institute assert that the largest oil companies have been in the forefront of the battle to protect the environment, especially groundwater and drinking water supplies from the hazards of petroleum contamination. 
CHAPTER II

GROUNDWATER HYDROLOGY

\subsection{Precipitation}

It is estimated that in over half of the states in our union, more than $50 \%$ of the population depends on groundwater as the major source of water for homes and industries. In only five states does groundwater fill less than $30 \%$ of the demand. ${ }^{4}$ Communities depend heavily upon groundwater to sustain current levels of development and must also protect reserves to supply possible future needs. As such a valuable community resource, groundwater merits protection to insure its potability and to insure sufficient quantities for present and future use. A majority of the cases of groundwater pollution can be directly attributable to the types of land uses associated with the land above or nearby the groundwater. In order to understand how land use involving the underground storage of petroleum products may pollute groundwater, it is necessary to have a basic understanding of how the hydrologic cycle operates in nature.

Precipitation in its various forms falls from the atmosphere to the surface of the land. Once on the ground, part of the precipitation runs off and follows the path 
of least resistance downward to join the rivers, lakes, oceans and streams of the surface water system. Another portion of the precipitation is absorbed by the foliage and root systems of the natural vegetative cover of the land where it is used to sustain plant growth. The portion of precipitation which runs off relative to the portion which is absorbed by the land depends upon surficial conditions such as soil type, slope and intensity of development (see Figure 2).

That remainder of precipitation which does not run of $\mathrm{f}$ or become absorbed by the natural vegetative cover of the land percolates through the soil more or less vertically until it reaches the zone of saturation of water table. The water table usually, but not always, roughly approximates the contours of the land formations on the surface above it. Intensive pumping of a groundwater aquifer may cause the groundwater to actually flow up gradient. But most often, like surface water, groundwater flows from higher elevations down gradient toward sea level. The water table meets the surface of the land in streams, lakes, ponds and rivers. Generally, groundwater flows very slowly, usually in the range of 5 to 50 feet per year. 5

\subsection{Aquifers}

The saturated soil materials found in the water table along with the groundwater itself, are collectively called the aquifer. The special properties of the soils 


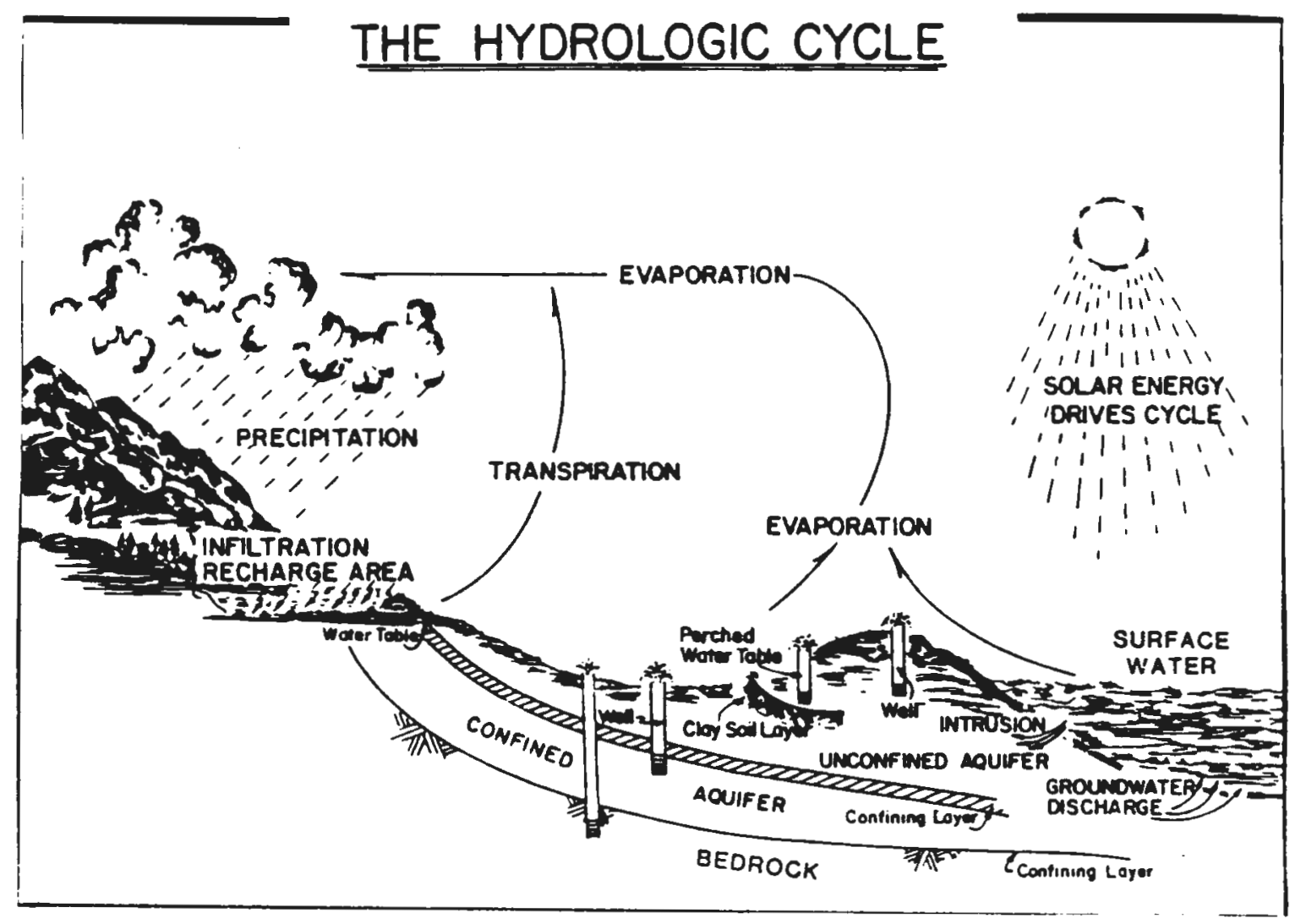

Figure 2

Precipitation will be absorbed by vegetative cover, percolate through soil to the groundwater, or else run off through surface water systems to streams, lakes or the sea.

Because of the interconnected nature of groundwater systems it can be readily seen how releases from underground storage can affect groundwater quality even in areas distant from the place of release.

Source: Nashua Regional

Planning Commission 
determine the holding capacity of the aquifer, especially the soil porosity (see Figure 3 ). The movement and melting of the glaciers of the last Ice Age have left large deposits of stratified sands and gravels which due to high porosity, have a large holding capacity for groundwater. Additionally, these stratified deposits, called outwash, are the easiest type of aquifer from which to draw water. Due to these special qualities, outwash deposits, provided that they are sufficiently thick and extensive, are considered to have potential as municipal water supplies. As such, they merit intensive protection from land uses which may compromise water quality through pollution.

Aquifers are also found in other types of soils, notably till. Till soils, which are made up of sands, silts, clays gravels and boulders are less stratified than outwash and have smaller pore spaces between the soil particles. Till may contain large amounts of groundwater, but extraction of this water is generally difficult. Therefore, while till aquifers will yield enough water to supply a few households, they are generally not considered to have potential as municipal water supplies.

Bedrock aquifers also occur in the fractures and fissures of bedrock deposits but groundwater supply potentials from bedrock aquifers are generally considered to be insufficient for municipal level water supply purposes. Yet if households or businesses use bedrock aquifers for 


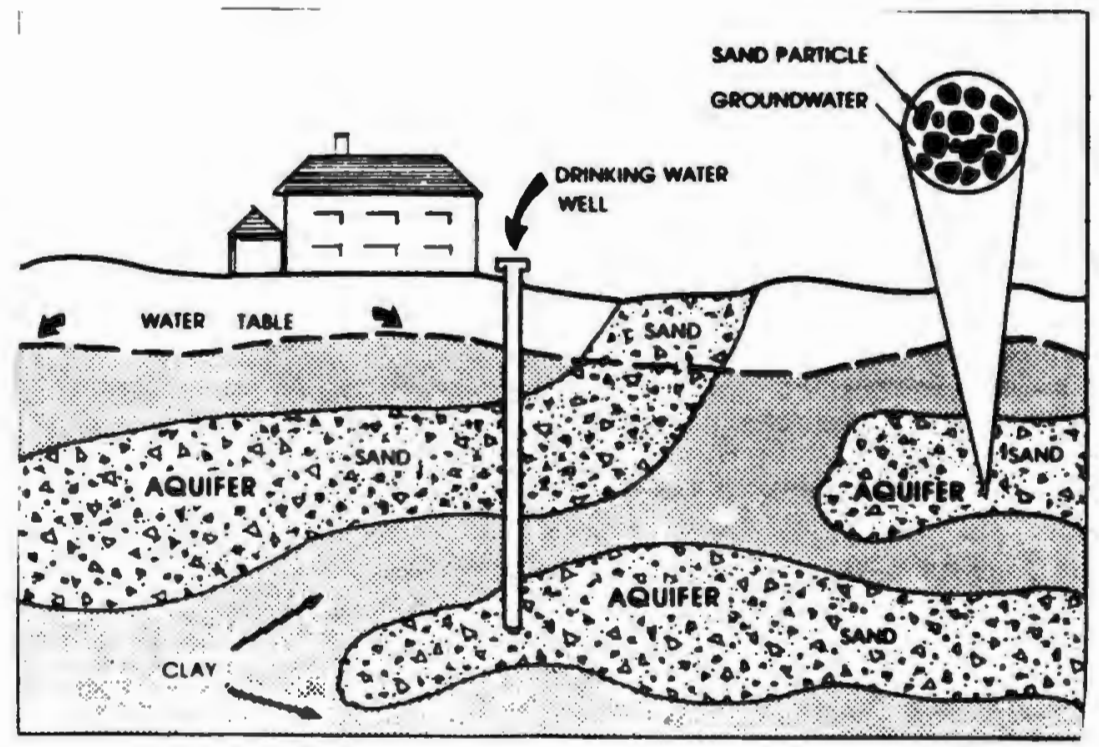

Figure 3.

Groundwater Aquifers

Aquifers are located within the water table and consist of deposits of sands and gravel of various sizes mixed with water. Potential yield of an aquifer depends upon particle size as well as an overall volume of the aquifer because particle size affects ease of water extraction. 
water supplies or if such a need can be reasonably anticipated in the future, these bedrock aquifers must be aggressively protected from potential sources of pollution. The recharge zone of an aquifer is that area of land located above and adjacent to the aquifer. Precipitation falls on the recharge zone where it permeates the surface and flows downgradient to the water table. The water then moves laterally to accumulate in the deep deposits of the aquifer proper, thus recharging it. Although an aquifer is continually recharged by precipitation, the holding capacity of an aquifer is fixed according to soil and bedrock conditions. Therefore, groundwater is properly considered a finite resource. 2.3. Contamination of Groundwater

Economic factors usually favor the development of groundwater resources for new water supplies over the more costly development of new surface water reservoirs. Further, conventional wisdom holds that while surface waters are susceptible to pollution from the atmosphere and from runoff, groundwater resources are viewed as pristine because of the natural ability of the soil particles to hold and bind any pollutant material. The conventional wisdom is wrong in the case of petroleum pollutants. Gasoline hydrocarbons have a relatively poor adherence to soil particles. Soils may slow the movement of leaked gasoline but they cannot be relied upon to capture the leak. ${ }^{6}$ 
Contaminants in groundwater generally move in a plume because there is little dispersion in the saturated zone due to the mixture of soils and water that comprise it.

Gasoline is made up of many components, some of which are soluble and some not. When released into the groundwater the insoluble components will tend to float on top of the water table while the soluble components will tend to disperse more widely. Gasoline components will also tend to mound on top of the water table; this mounding will tend to effect the direction of flow of the groundwater. 7 Thus the behavior of gasoline in the groundwater is difficult to predict. The potential exists for even a small leak to contaminate millions of gallons of groundwater. In addition to the problem of the contamination of drinking water supplies, some volatile gases emanate from the gasoline and rise vertically through the soil where they may eventually permeate building materials and sewer pipes. These gases present a considerable risk for fire and explosion. In fact, petroleum tanks were originally forced underground as a public health measure to protect people from fire hazards. Today public health concerns ironically top the list of problems posed by petroleum contamination of groundwater and soil. 8 


\title{
CHAPTER III
}

\author{
FEDERAL REGULATION FOR THE UNDERGROUND STORAGE \\ OF PETROLEUM PRODUCTS
}

\subsection{The Role of the Environmental Protection Agency Section 9003 of the Resources Conservation and Re-} covery Act as amended directed the Environmental Protection Agency to promulgate rules and regulations pertaining to the underground storage of petroleum and other hazardous substances. A regulatory scheme was developed which encompassed all aspects of the issue including requirements for leak detection, leak prevention, financial responsibility and corrective action.

The proposed rule is currently under consideration. After an appropriate period for public and industry comment, the final rule will be adopted by May 1988. The following is an outline of the major provisions of the proposed rule as it appeared in the Federal Register of April 17, 1987. While it is not certain that the final adopted rule will be identical to the proposed rule, it is expected that, with one exception to be examined below, most sections of the rule will be adopted as proposed. The EPA was very painstaking in its consideration of all comparable approaches to the steps it perceived as necessary to the 
containment of the problem of leaking underground storage tanks.

3.2. Exclusions to the Proposed Rule

The rules apply to all owners of underground storage tanks which contain a volume greater than 1,100 gallons and which are used to store petroleum products or other hazardous substances. Tanks are considered to be underground if at least $10 \%$ of the volume, including pipes, is located below the surface of the ground. Exceptions to the rule are as follows:

- Septic tanks

- Tanks storing heating oil for use on the premises where stored

- Pipeline facilities regulated under the National Gas Pipeline Safety Act or comparable state acts

- Surface impoundments, pits, ponds and lagoons

- Stormwater and wastewater collection systems

- Flow through process tunnels

- Liquid traps or associated lines directly related to oil or gas

- Storage tanks situated on or above the floor of underground areas such as basements, shafts or tunnels.

3.3. Summary of Proposed Federal Rule

The regulatory measures as proposed would establish requirements for both new and existing UST systems. The rules are intended to control the major causes of releases 
from these tank systems. The major elements of this proposal are as follows:

- A11 new UST systems must be designed and constructed to retain their structural integrity for their operating life, including the use of corrosion protection of metal components. Cathodal protection must be monitored and maintained to insure that UST systems remain free of corrosion.

- Proper installation standards must be followed when putting a new UST system into service. The owner and operator of the UST must certify that correct installation procedures were followed and must identify how the installation was conducted.

- Owners and operators of both new and existing UST systems must immediately follow proper tank filling practices to prevent releases due to spills and overfills. In addition, owners and operators of all new UST systems and existing UST systems equipped with external release detection must use devices that prevent spills and overfills.

- Tanks can be repaired, but only once, if they are in sound enough condition to be repaired. Recommended industry practices must be followed to conduct repairs, and in addition, several tests must be conducted to ensure quality repairs. 
- Inudstry recommended practices with regard to tank system closure must be followed, and accordingly, the UST system must be removed from the ground or left in place after removing all regulated substances and closing it off to all future outside access. In addition to these regulated industry practices, all owners and operators must perform an assessment at the time of tank closure to ensure that a release has not occurred. If a release has occurred the appropriate corrective action must be initiated.

- Release detection must be instituted at all UST systems. Secondary containment systems and interstitial monitoring will be required for all USTs containing hazardous substances. Petroleum UST systems will be allowed to use several different methods for release detection, although requirements concerning their use must be adhered to by tank owners and operators.

- Release detection systems must be phased in at existing UST systems over a 3 to 5 year period. Bare steel UST systems unprotected from corrosion are required to phase in release detection systems within the shorter period of time.

- Requirements for reporting releases are established. Indications of a potential release would have to be reported to the state implementing agency, 
including positive results from release detection methods that have been immediately investigated by owners and operators. After reporting releases, release investigation and confirmation must take place and where necessary, corrective action must take place.

- All existing UST systems must be upgraded or replaced to new tank standards within 10 years, or within 3 to 5 years if a release detection method is not available that can be relied upon to detect releases. Upgrading of petroleum UST systems would include retrofitting of corrosion protection and spill and overflow controls at all tanks (see Figure 4).

- Owners and operators of leaking UST systems must follow prescribed measures for corrective action. Immediate corrective action measures include mitigation of safety and fire hazards; removal of saturated soils and floating free product; and an assessment of the extent of further corrective action required. A corrective action plan would be required for long term clean-ups addressing groundwater contamination. Clean-up levels would be established on a site by site basis as approved by the implementing agency (usually the state) that would oversee the clean-up by the owner and operator. 
Typical Underground Storage Tank Installation

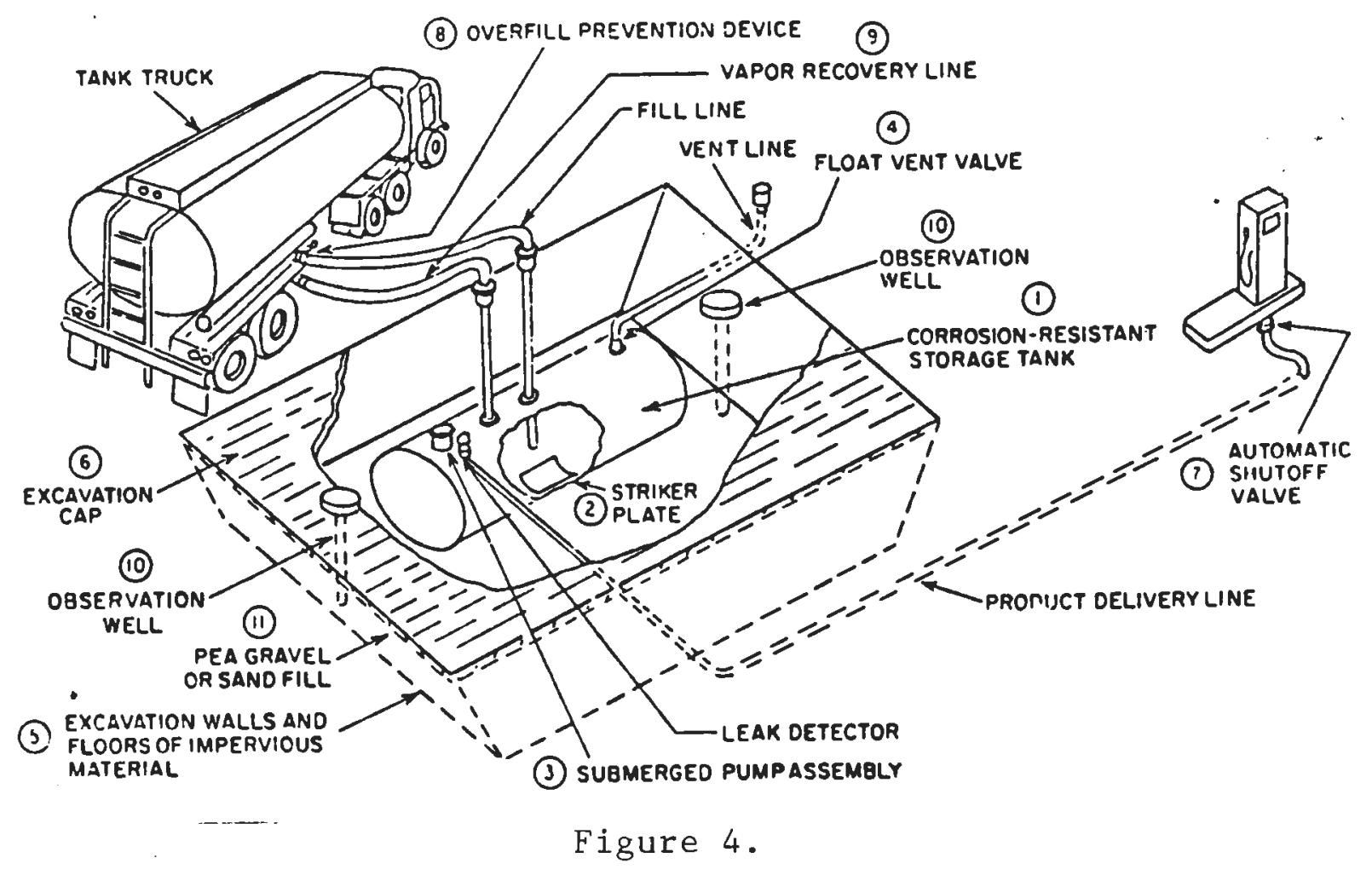

This is a common type of tank installation that might be found at a recent gasoline retail outlet. Proposed federal regulation would significantly change and upgrade an installation such as this with double walled tanks and leak detection devices.

Source: The Community Tank Census 
The EPA considered requiring more stringent containment systems for tanks located in environmentally sensitive areas. The idea of developing a class system for required containment based upon location in an environmentally fragile area was eventually rejected due to the difficulty in establishing criteria at the federal level for these sensitive areas. It was determined that state and local implementing agencies would be better equipped to determine those geographical areas which would merit extra protection and that it would be within the authority of the implementing agency to establish more stringent requirements than those set forth by the EPA. Since the overall success of regulation of USTs depends so heavily on state and local enforcement, it was felt that the implementing agencies would be better able to enforce the rules without the extra layer of regulation a federal standard of environmentally sensitive areas would present. 3.4. Financial Assurances

In addition to the above requirements, owners and operators of all new and existing UST systems will be required to produce financial assurances demonstrating the capability to bear the costs of clean-up of releases. As clean-up costs can be extremely expensive, the EPA has recommended that each owner and operator be required to carry one million dollars insurance coverage per UST system. The obvious financial burden created by this requirements is the cause of some concern within the 
petroleum industry, especially the small business retailers. It is indeed expected that UST upgrading requirements, coupled with increased insurance requirements, will force some of the small marginal retailers to close their doors. Despite this unfortunate effect, the EPA believes that public health considerations far outweigh the problems presented to some small businesses by the proposed comprehensive UST regulatory program.

Beyond the objections by small businesses to the additional financial burden placed upon them by the financial assurances clauses of the proposed rule, the insurance industry, which would be the providers of most of the coverage, has expressed some reluctance to offer policies on a large scale to the small businesses. At the time of this writing, in fact, insurance coverage for small tank owners is difficult, if not impossible to obtain. Many tank owners are currently covered by comprehensive general liability policies. These policies usually cover sudden accidental leaks but do not cover gradual pollution--the most typical sort of leak that results in groundwater contamination.

One insurance broker described the industry stance as a reluctance to aid and abet the pollution of the environment by taking the financial responsibility for cleanup out of the polluter's hands. The feeling is that if a UST systemoperator does not have to worry about the financial consequences of a release, the incentive to take 
precautions will be less storng. The insurer could be made to pay for clean-up when the accidental release might have been prevented. Whether this sentiment is widely held among major insurers is unclear.

The insurance industry bases its prices for coverage upon detailed statistical analysis of risk. At the present time, it is questionable whether sufficient data exist for the insurance industry to develop a firm and fair basis for charging tank owners for pollution clean-up coverage. There are many factors relative to tanks which may or may not be closely associated with a propensity towards leaks, among these factors are tank age, tank material, installation methods, piping materials and whether the tank has been repaired or relined. Extensive statistical analysis of all these factors must be accomplished before insurance rates can be set. Beyond tank variables, site variables associated with leaks must be analyzed. These variables may include soil conditions, slope, proximity to the water table, proximity to earthquake fault lines and a host of others. It is clear that the insurance industry would be required to perform enormous and time consuming studies to determine fair rates for individual tank owners. The EPA thus expects a high degree of input from the insurance industry during the public comment period prior to the promulgation of a final rule in May, 1988.

Under the proposed rule there are several other ways a UST owner can demonstrate financial reponsibility for 
clean-up and damages due to releases. They are:

- Proof that the owner/operator's net worth is at least 10 times the required annual amount of coverage. The required annual amount of coverage is between $\$ 1,000,000$ for a single UST to $\$ 6,000,000$ for the owner of 341 or more tanks.

- Arrange for someone else to be responsible for clean-up and damage costs. Methods may include guarantee, indemnity contract, surety bond or letter of credit. There are strict requirements for these methods.

- If EPA has authorized your state to administer its own program for USTs, any method of coverage approved by your state may be used.

- If your state has established a clean-up fund that will pay for the costs of a leak then additional coverage may not be needed for the same costs. However, financial responsibility for costs of compensating those injured by leaks will still be the responsibility of the owner/operator, unless the state would also pay for those costs. ${ }^{9}$

3.5. The Trust Fund for Leaking Underground Storage Tanks As alluded to above, through the same amendments Congress provided Federal funds to clean-up petroleum leaks and spills from underground storage tanks. The Trust Fund for Leaking Underground Storage Tanks will strengthen current clean-up and enforcement efforts of 
many states and localities.

The UST Trust Fund is being financed by a tax of $1 / 10$ of one cent per gallon on motor fuels which will raise $\$ 500$ million dollars over the next five years. The majority of these funds will be made available to the states. The EPA wants the states to enter into cooperative agreements which will specify how the Trust money will be used. The role of the states is deemed extremely important because the EPA believes that state officials are generally closer to the scene and know more about tanks in their states and local site conditions than federal officials. 10

States can order, as well as conduct, clean-up operations. EPA and the states may compel the tank owners or operators to undertake, or to pay for, any of the following actions :

- Test tanks for suspected leaks;

- Excavate a site to investigate the extent of contamination;

- Assess how many individuals may have been exposed to petroleum contaminants and the seriousness of their exposure;

- Clean-up contaminated soil and water;

- Provide safe drinking water to residents whose supplies have been contaminated by a tank leak;

- If necessary, relocate residents temporarily or permanently. 
Although states may be provided with funds to remediate leaks through the Trust Fund, it is expected that most states will use the funds for improving enforcement and reporting procedures. The Trust Fund gives the states the flexibility to act immediately in a dangerous leak situation, but the intention of Congress is that tank owners should pay for clean-up costs and damages. After regulations go into effect, the EPA expects that the Trust Fund money will be used primarily for emergencies and clean-ups in which:

- Costs exceed the amount of coverage that tank owners and operators are required to maintain, and Fund expenditures are necessary to assure an effective corrective action;

- A solvent owner or operator cannot be found; or

- The owner or operator fails to comply with a clean-up order. ${ }^{11}$

States will be required to repay $10 \%$ of the Trust Fund money that will be used for clean-up operations after the regulations take effect. Tank owners and operators will be required to repay EPA or the state for clean-up costs. The existence of the Trust Fund in no way cancels the financial assurance requirements of the proposed regulations scheduled to take effect in May, 1988. 
CHAPTER IV

\section{STATE AND LOCAL INITIATIVES FOR CONTROLLING \\ LEAKING UNDERGROUND STORAGE TANKS}

\subsection{Background}

Inherent in the federal proposals for the upgrading of UST's and protecting humans and the environment from the hazards of product releases is the belief that officials of states and localities have more complete knowledge about tank and site conditions in their own geographic areas than do federal officials. The proposed rule is designed around allowing and encouraging state officials to develop their own implementation plans and tank standards relative to the varying degrees of environmental sensitivity and dependence upon groundwater in their areas. States have the right to develop and enforce more stringent regulations and standards than the proposed federal rule requires. States may require specific tank systems and demand certain types of testing procedures.

The Underground Storage Tank Trust Fund is made available for discretionary use by the states upon entering into an agreement with the EPA concerning Fund uses. The Trust Fund proposal reiterates the faith of Congress and the EPA in the fitness of state officials to develop effective 
and efficient programs tailored to the specific conditions in their own localities.

4.2. State Regulatory Programs: The Rhode Island Example In response to federal policy, the state of Rhode Island has been in the forefront of planning and enforcement efforts regarding UST's. Rhode Island has developed its own regulations based upon its extensive reliance on groundwater and other environmentally sensitive conditions found in the state.

The following is an outline of Rhode Island's strategies concerning containment of UST hazards. It is presented as an example of a high quality, comprehensive program that addresses the needs of UST owners as well as public health and environmental protection. While several states have thus far mandated their own tank standards, Rhode Island may be unique in its offer of assistance to tank owners.

The Rhode Island program has four major components:

1. Rules and Regulations. These are tailored to existing environmental conditions across the state.

2. UST Revolving Loan Fund. This provides low cost loans to small business tank owners.

3. UST Trust Fund. Supplements budget of Rhode Island Department of Environmental Management for UST's. 
4. Emergency Response Fund. Provides flexibility for quick response to danger from UST leaks. Rules and Regulations. The following administrative findings provided a basis for the Rhode Island regulations:

a. Approximately $30 \%$ of the population of Rhode Island depends upon groundwater as a sole or principal source of water supply.

b. The principal groundwater resources of the state are located in relatively thin glacial deposits of stratified sand and gravel which underlie about one-third of the state. These aquifers lie close to the surface and are extremely vulnerable to contamination.

c. A number of small public and private water supplies obtain water from till covered fractured bedrock aquifers which underlie about two-thirds of the state. These aquifers are especially difficult to monitor and to reclaim once contaminated.

d. A large portion of the state's future water supplies will be developed from groundwater resources due to the limited number of suitable sites for the construction of surface water reservoirs.

e. The rapid escalation of groundwater contamination by petroleum products continues to cause property damage and poses an imminent peril to human 
health by the migration of product and/or product fumes into underground utilities and basements throughout the state. 12

Appropriate to these conditions, Rhode Island has developed rules and regulations somewhat more stringent than those required by the EPA proposed rule. Some of the distinctive features of the Rhode Island rules and regulations are:

- New or repaired tanks must comply with one of three requirements which are secondary containment, approved continuous monitoring system coupled with periodic precision testing, or double walled tanks fitted with interstitial monitoring and secondary containment for pipes. ${ }^{13}$ (See Figure 5.)

- Designated environmentally sensitive areas have been mapped out by the state. Tanks located in these areas must be equipped with monitoring wells.

- Tank testing requirements have been increased above EPA recommendations. Older tanks must be tested at $5,8,11$, and 13 years and annually thereafter. New tanks must be tested at installation and every five years thereafter.

- Spill containment will be required for all tanks.

- Tanks may only be repaired or relined once, and then only with a method approved by the Director of the Department of Environmental Management. 


\section{LEAK DETECTION METHODS}

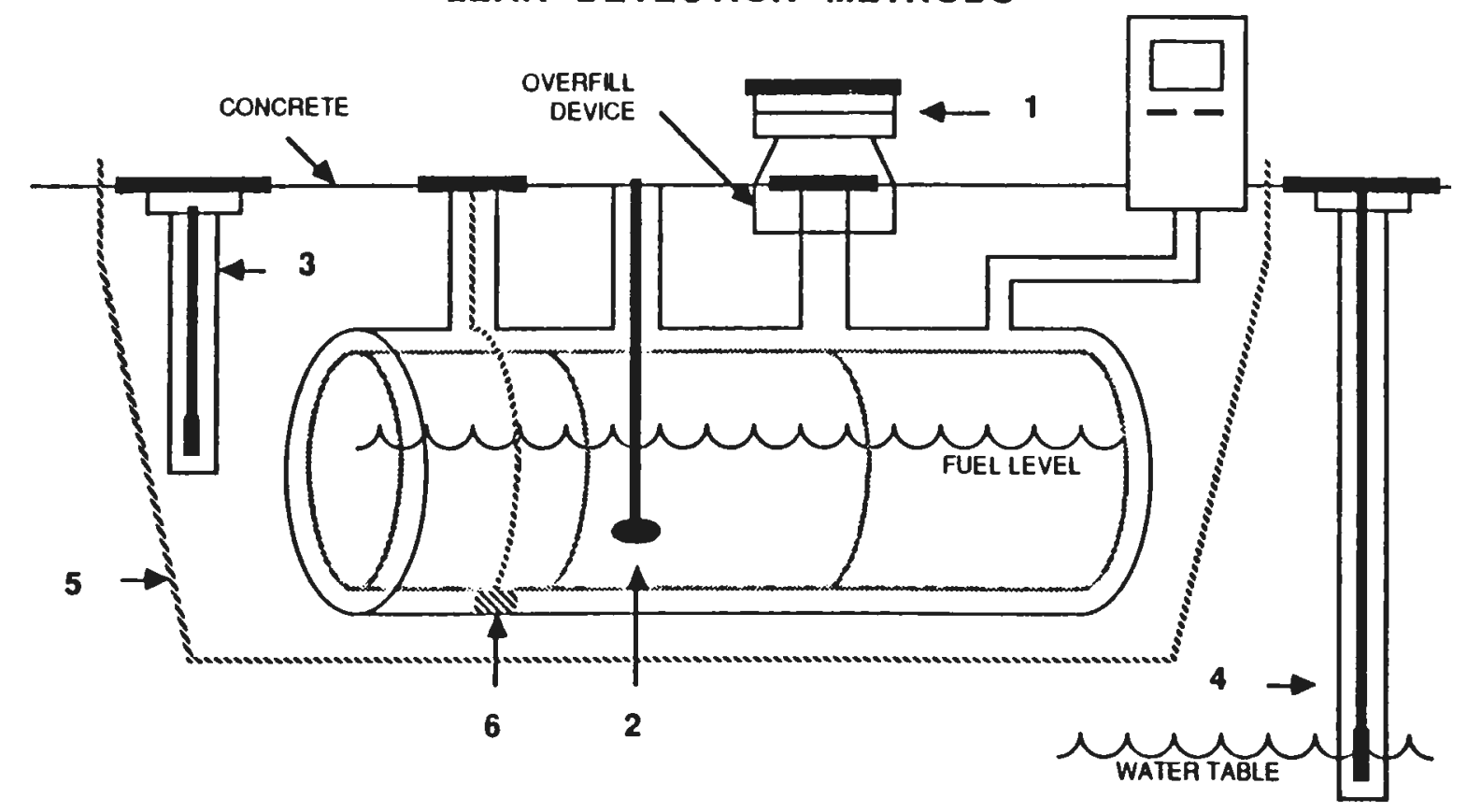

\section{1 - TANK TIGHTNESS 3 - VAPOR MONITORING 5 - INTERCEPTION BARAIER TESTING IN THE SOIL \\ 2 - IN TANK MONITOR 4-GROUND-WATER \\ 6 - DOUBLE-WALL TANK WITH INTERSTITIAL MONITORING WELL MONITOR}

Figure 5 .

Above are shown various types of methods approved by the EPA for detecting releases from underground storage tanks. State regulations vary and some may exceed federal regulation. Some leak detection methods shown above may not satisfy all state regulatory requirements for leak detection methods. 
The cautious approach of Rhode Island while being environmentally appropriate obviously places a financial burden on small gasoline retailers and other small business and private tank owners, especially when increased financial assurance requirements are considered. In response to this issue, Rhode Island has instituted a Revolving Loan Program especially for UST owners. Under this program, tank owners are eligible for loans at a subsidized rate ( 2 pts. below 6 month T. Bill rate). The use of the fund is restricted to the upgrading and replacement of tank systems. The loan program is especially targeted for small business and private tank owners as most of the major national retail gasoline chains and major oil companies have already introduced tank replacement programs, having had ample resources of their own to do so. As loan funds are limited ( $\$ 1$ million dollars in the first funding cycle) a weighted score system is applied to all applications. This scoring system is designed to determine how likely a leak occurrence is in each particular tank and how great the damage might be should a leak occur. According to DEM sources, applications have been forthcoming from the desired small business and private sector. 14

Some problems have been identified in the process. For example, the application itself is lengthy and detailed; it is expected that staff may be needed to assist some tank owners with the application process. Also, a 
contractor to perform credit worthiness checks has yet to be retained as there was some difficulty in assessing a fair price for these services. Both these problems are expected to be solved as the program evolves. Full scale tank replacements are expected to cost about $\$ 80,000$ per tank. 15

Trust Fund. Passage of the federal UST Trust Fund in 1986 established a new tool for the implementation of tank programs. Rhode Island was among the first states to respond to this initiative and entered into a cooperative agreement with EPA this year. In Rhode Island the Trust Fund monies are used primarily for staff to enhance enforcement and response capabilities. Specifically, new staff members have been hired to better utilize information and to follow up on noncompliance with tank registration regulations. Better tracking of underground tanks has led to quicker response to cleanup and remediation situations. A full time attorney was also hired to assist with enforcement, compliance and recovery of state incurred clean-up costs from tank owners.

Emergency Response Fund. In emergency situations requiring immediate clean-up actions, the DEM has at its disposal monies from a contingency fund which may be used for clean-up and remediation where public health and safety are threatened. In these cases, the state has the flexibility to immediately order and pay for tank closure, clean-up, soil removal, environmental restoration and other 
remediation activities. The owner/operator is later billed for the costs. As the owner of the land on which the tank is located is ultimately responsible for damages, and since land is always worth something, it is not expected that the state will have to bear the costs of clean-up and closure except in cases where the costs exceed the value of the land.

Rhode Island was quick in responding to all federal initiatives regarding the containment of hazards from leaking UST's. Its rules and regulations are stringent but they are based on careful assessment of groundwater resources and estimated present and future demands placed on these fragile aquifers. The Rhode Island program was based on careful environmental and demographic research. As such it fulfills the purpose of Congress and the EPA to allow state officials with their specific knowledge of existing local conditions develop specialized programs tailored to specific environmental and public health considerations.

The Revolving Loan Fund displays a commitment to small business and promotes a healthy economic environment as well as physical environment. This important program is very likely to be copied in other states.

(Small business tank owners in other states may be interested in obtaining the EPA document Assistance Programs for Pollution Control Financing. It outlines funding 
assistance available primarily through the Small Business Administration.) 
CHAPTER V

COUNTY AND LOCAL UNDERGROUND

STORAGE TANK INITIATIVES

\subsection{Background}

The proposed federal rule on Underground Storage Tanks and the UST Trust fund both espouse a commitment to formation of control policy at the state and local level wherever possible. This stems from the opinion that state and local officials have better knowledge of special groundwater, tank, soil and demand conditions in their own areas. States have been invited to develop programs more stringent than the proposed rule if conditions merit a more cautious program approach. Beyond even this, counties and municipalities are encouraged to develop more stringent regulation programs than the proposed federal rule. This federal policy demonstrates a commitment to local control and faith in local planning endeavors. The policy was also deemed a necessary component to an effective hazard control program as states are not required to adopt their own regulation policies above and beyond the proposed federal rule. In fact, most states have chosen not to develop their own programs but are instead waiting for the expected adoption of the proposed federal 
rule in May, 1988. At that time most states are expected to adopt quite similar or identical to the federal program. Assuming, as the federal government does, that certain local conditions will require a closer analysis and stricter regulation, counties and communities should mobilize to develop their own programs. This is particularly true if they happen to be located in states that do not intend to develop their own special programs beyond what will be required by the federal rule. Local officials often have quite intimate knowledge of local environmental conditions and are thus often well equipped to act to prevent costly environmental and public health damage from leaking USTs. Many counties and municipalities across the country are currently developing or administering their own programs. An important inclusion in local programs might be registration and standards for tanks containing less than 1,100 gallons as the proposed federat rule exempts these tanks from regulation. However, a small amount of petroleum product has the potential to do a great deal of harm if released into a fragile groundwater environment. Therefore, local officials should analyze conditions to determine if these smaller tanks require regulation. If groundwater dependence is great and aquifers of a small capacity then regulation of small tanks might be a necessity.

In April of 1987 the New England states suffered through an immense rainfall which resulted in very severe 
flood conditions, especially in Maine. Flood damage was compounded by many release incidents involving USTs. Statistics gathered by the state of Maine revealed that:

- The Augusta regional office reported 32 spills resulting in 130,000 gallons of petroleum products released into rivers. In addition, 3 USTs popped up from underground and floated away.

- The South Portland office responded to 21 spill reports which released an estimated 17,000 gallons. Six USTs were also lost.

- The Bangor response team answered called on 10 spills which released an estimated 15,000 gallons. Two USTs escaped down the river. ${ }^{16}$

The flood situation which gripped these Maine counties points up the need for strong individualized local programs to protect against the hazards that leaking USTs present. Several types of vehicles exist for controlling these hazards, some regulatory and some non-regulatory. 5.2. Local Control of UST Hazards

Local officials interested in developing a protection program at the outset need to identify their own locality's reliance on groundwater, existing and proposed development and the political, social and economic issues associated with implementing groundwater controls and the protection of their groundwater resource. Prior to taking any major legal steps, officials should obtain USGS Groundwater maps, surficial geology maps and available information 
from the Soil Conservation Service. The strength of any groundwater ordinance is critically dependent on the level of scientific data which exists to support it at the time of its adoption.

The following is a discussion of some regulatory devices that counties and localities may employ if local conditions prove to warrant expanded protection against the hazards of leaking USTs.

UST Ordinance. Several cities and counties across the country have adopted local ordinances mandating tank registration, testing, leak monitoring, spill protection and closure procedures. These regulations tend to mirror the federal proposed rule but usually increase standards relative to environmentally sensitive areas. Often small tanks are regulated by local tank ordinances as well.

Overlay Zoning. Pollution of groundwater is almost always associated with the land use above or adjacent to the aquifer. Zoning by-laws and regulations are used to establish land use districts. Overlay zoning is often used to separate incompatible land uses from areas where groundwater is susceptible to contamination. An overlay zone is defined as a set of restrictions which are applied in addition to district zoning requirements. ${ }^{17}$ overlay zoning may be used to regulate or limit USTs in the following sensitive areas:

- Aquifers

- Watersheds 
- Wetlands

- Flood plains

- Stream belts

- Coastal areas

Conditional Use Permit. This is a device established by the zoning regulations which allows certain land uses subject to review by the planning board and proof that standards set by the planning obard will continue to be met. The planning board, in approving the conditional use permit may impose restrictions or conditions on the development of the premises such that possible adverse effects on public health and safety are minimized. Conditions that are set forth in a conditional use permit are expressly set forth in a resolution granting the permit. The applicant must unconditionally agree to all conditions imposed on the approval in writing. Prior to granting the conditional use permit for a UST, the planning board must carefully study local conditions and consult with public health officials and the fire marshall to determine what level of protection is required locally and what steps the UST applicant should take to minimize any possible adverse effects on the groundwater resource and the public health and safety. Tank characteristics which might be required beyond the federal proposed rule for environmentally sensitive areas might be:

- Secondary containment

- Continuous inventory monitoring 
- Precision leak testing

- Upgraded leak testing schedule

- Increased insurance requirements

Recent information shows that a substantial percentage of leaks come from home heating oil tanks. Regulation of these tanks should be of considerable importance to local communities. Besides the large number of tanks involved, an even greater reason to regulate these tanks is because of their lighter gauge and unprotected steel construction. ${ }^{18}$ Some state and federal regulations are too rigorous, too expensive or not applicable to residential and small nonresidential tanks. Appropriate regulations can be incorporated into local provisions and used effectively to regulate these small tanks through local efforts. 5.3. The Community Tank Census

Since the need for local intiatives to control groundwater protection from leaking UST hazards cannot be overemphasized, innovative strategies must be considered. The Nashua Regional Planning Commission espouses the Community Tank Census approach. This approach has certain advantages over strict land use regulations, as land use regulations can only restrict future uses of land. Hazards from leaking USTs usually come from tanks which have already been buried in the ground a number of years. In fact, abandoned tnaks constitute a considerable portion of the total threat from leaking USTs. Prior to conducting a community tank census, the community must organize a 
water protection program so that high priority areas may be established and a tank census may be concentrated in the areas where it is most needed. A Water Resource Protection Board should be appointed to oversee the census. With broad membership, such a committee can increase local awareness of potential pollution problems. Registration of all tanks should be a part of any local policies to prevent leaking USTs.

With community endorsement and a sufficient budget and well defined objectives, a census can be efficiently conducted to yield important groundwater protection information. A census form could also serve as a tank registration form, thereby enhancing local knowledge of tank conditions in the locality. A census advisory committee should be established to provide technical assistance and might be composed of a town engineer, a conservation commission member, a health officer and interested persons who have knowledge of the historic land uses in the town. A census task force must actually conduct a search. As a basic plan, municipal records, tax maps, records of the building inspector, and records of the fire department ought to be examined to determine the location of all tanks, active and abandoned. A mailing program is usually part of the census.

In the absence of sufficient funds to cover contractor services for the tank survey, volunteer labor must be extensively utilized to complete the task of 
registering all UST's in a given area. While a tank census might be an arduous and lengthy taks, communities with high dependence on groundwater should consider a tank survey to be supportive of their long-term interests in economic growth and environmental quality.

5.4. Enforcement

Federal, state and local programs of hazard protection geared toward the prevention of groundwater pollution from leaking UST's may be developed with accuracy and sensitivity yet all are rendered useless without a strong enforcement component built into the regulations. Insofar as local regulation is concerned, town, county and city enforcement officials contribute much to the actual reduction of pollution risk. Local officials, with their intimate knowledge of local conditions, are often in a position to know tank owners and inform them of tank registration and permitting requirements. Also, state requirements for tank registration will of ten trigger an inspection by a local official in cases of commercial, industrial and governmentowned tanks. The local official who usually performs such inspections is either the fire marshall or the mechanical plumbing inspector.

Mechanical inspectors and fire marshalls of ten work closely together when involved with underground storage tanks. In the case of new tank installations, both officials would have input into the approval of plans at the preliminary stages of a proposed tank installation. After 
installation, local officials may again have input by way of inspection for compliance with plan specifications and local codes.

In Rhode Island, although required tank tightness testing is performed by contractors employed by the Department of Environmental Management, local officials are always notified when a test is scheduled. The Rhode Island regulations promote a great deal of reciprocal communication between state government and local officials. By doing so, the regulations combine the resources and authority of the state with the local knowledge of the municipal officials and bring them together upon the problem of leak detection and prevention. Local enforcement is invaluable to bringing local tanks into compliance with state regulation. 


\section{STATE OF RBODE ISLAND \\ DEPARTMENT OP ENTIRONMENTAL MANAGEMENT \\ DIVISION OR WATER RESOURCES}

AULBORITY: Cbapter 46-12, 42-35, 42-17.1 and 23-19.1 of the General Laws of Rhode Island, 1956, as amended.

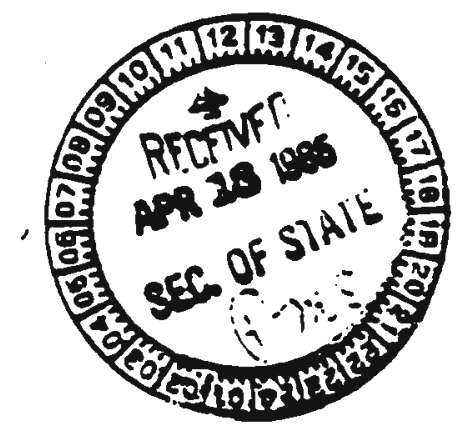


BECTIATIONS FOR ONDEBGROOND STORAGS FE :IIITIES

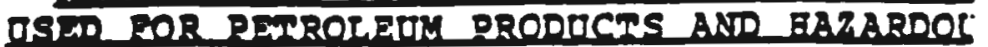

\section{OTHWTNE}

Section 1. Autbortty............................ I

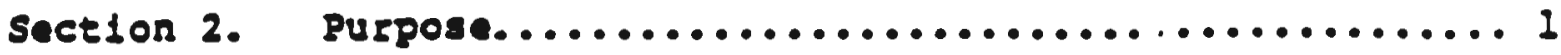

Section 3. Superseded Rules and Regulations.............. I Section 4. Administrative Findings.................... I

Section 5. Applicability......................... 2

Section 6. Definitions........................... 2

Section 7. Facility Registration.................... 7

Section 8. Denial, Modffication or Rerocatior of Certificate of Registration.............................

Section 9. Existing Facillty Requifements...............10

Section 10. New Facility Requirements...................11

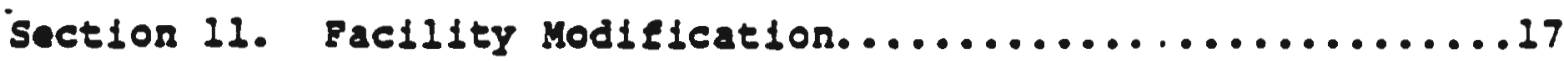

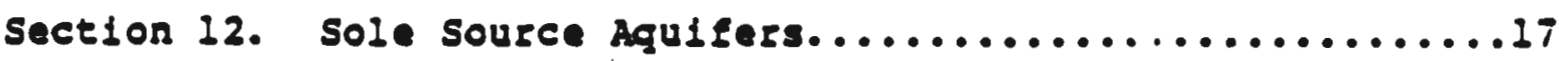

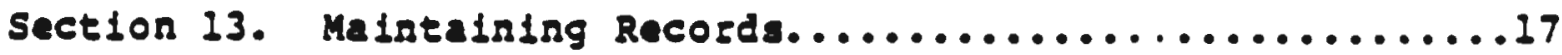

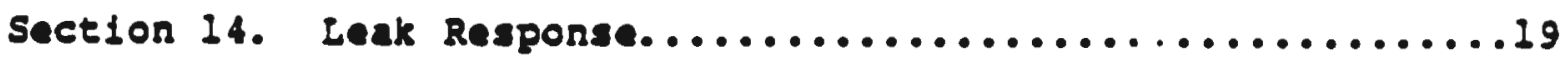

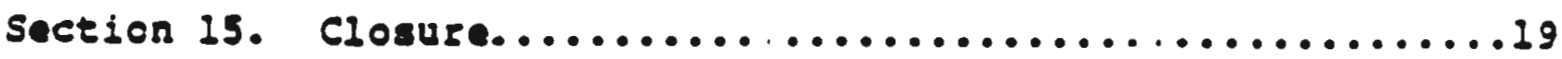

Section 16. Signatories to Registration and C: isure

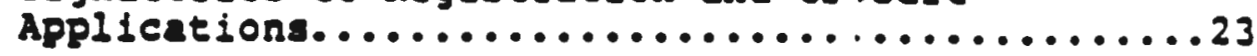

Section 17. Teansfer of Certificates of Regist ation

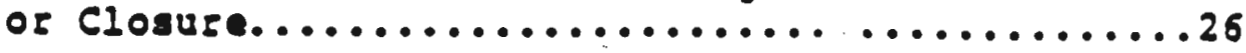

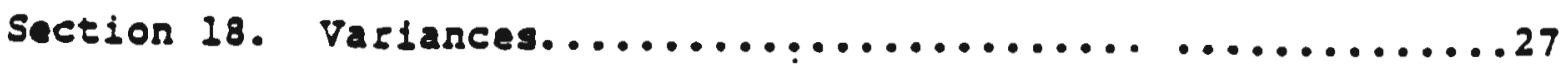

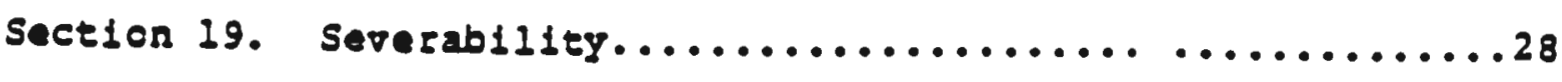

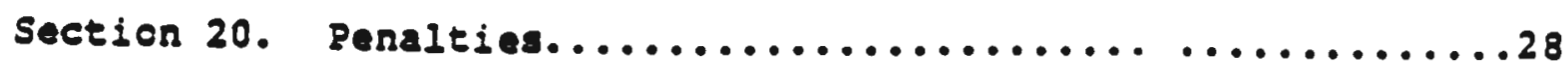


Appendix A. Definftion of Eazazdous Substance...............

List 1 Bazardous Substances - Clean water Act -

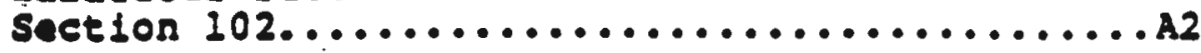

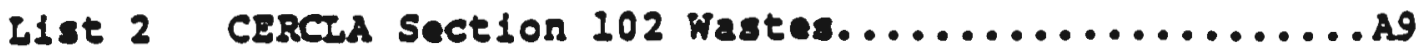

L1st 3 Toxic Pollutants - Clean water Act -

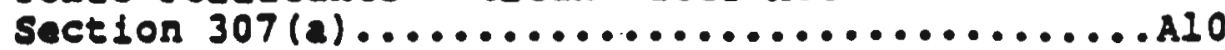

List 4 Bazardous Ais Pollutants - Clean Air Act -

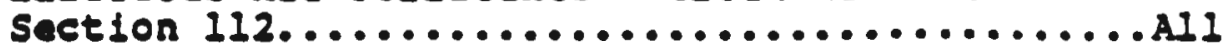

List 5 Iminently gazardous Chemicals - Toxic

Substances Control Act - Section 7...........Al2

Appendix B. Some Suggested Specifications Applicable to

Regulatory Requi rements........................ 
These regulations are adopted pursuant to Chapters 46-12, 42-17.1, 42-35 and 23-19.1 of the General Laws of Rhode Island, 1956. as amended.

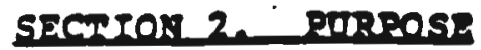

The puspore of these regulations is to implement a rogistration rystem and to establish facility design

requifements testing schodules, and closure requirements for new and existing underground storage tank system in order to protect the groundwaters and surface waters of the state from pollution that way result from the underground storage of petroleum products and bazardous materials.

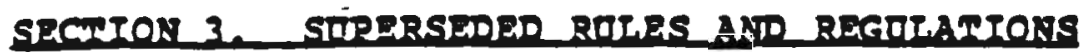

These rules and regulattons supersede the Emergency Regulations for Underground Storage Facilities Uaed for Petroleum Products and Bazardous Materials.

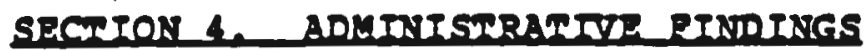

The following administrative findingo are also made a basis. for these regulations:

(a) Approximately 308 of the population of Rhode Island depends upon groundwater as a sole or principal source of water supply.

(b) The principal groundwater resources of the state are located in relatively thin glactal deposits of stratifled sand and gravel which underlie about one-thisd of the state. These aquifers lie close to the surface and are extramely vuinerable to contamination.

(c) A number of small public and private water supplies obtain water from till-covered fractured bedrock aquifers which underlie about two-thizds of the state. These agulfers are especially difficult to monitor and to reclaim once contaminated.

(d) A large portion of the state's future water supplies w11l be developed from groundwater sources due to the Iinited number of suitable sites for the construction of surface water reservoifs.

(e) The rapid escalation of groundwater contamination by petroleum products continues to cause property damage and poses an imminent peril to human health by the igration of product and/or product fumes into underground utilities and basements, tbroughout ou: state. 
(a) These zegulations apply to now, exlsting and abandoned facilities at which petzolaum product(s) andor hasazdous material(s) sezving institutions or Ladustrial, commerclal, educational, agficultural of govermental operations are stored undergzound.

(b) Excopt for Section 14, Leak and Sp111 Response, these regulations do not apply tos

(1) On-o1te underground storage takks used for storing beating ofl and sesving a one, two or three fandly dwellings

(2) Sarm or restdential underground storage tanks bolding less than 1,100 gallons and storiag motor tuel or heating ofl for ros-commerctal purposes:

(3) Soptle tanks

(4) Storage taiks located in an underground area, that 18 not past of a secondary contatninent gystem such as a bascment or collag, if the tank is steused upon or abore the suzface of the 10058 ar

(5) Jaderground storage tanks used for stortag Mo. i. No. 5 or No. 6 Euel oll.

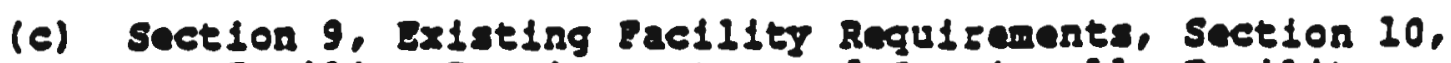
How Fac1lity Regulfements, and Section 11, Fac1l1ty Modiflcation do not apply to tanks used for storing Bo. 2 fuel or jet propulstor suel (Jp-l).

(d) Section 13. MaLntaining Records, paft (a) (6) does not apply to tanks used for storing fuel oil No. $1,1-0$ or 2 on site for consumptive use, or to tanks used for storiag waste oll.

(e) These regulations shall be construed is bacmony with and in addition to any requlfements of Rbode Island General Law Itte 23, Chapters 28.21 and 28.22 or any orders by local 1150 chless lssued thereunder.

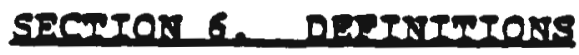

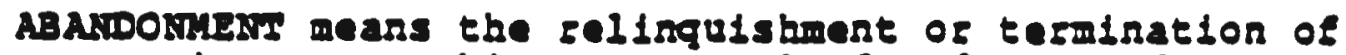
possession, ownership or contzol of underground storage tanks, by vacating or by disposition. Without meeting the closure zequifements listed in section is of these ingulations.

ClOSUR means the removal trom se:vice of any underground storage tank in accordance with tae procedures contained in these regulations. 
COMMENCED CONSTROCYION means that the owner or operator bas obtained local approvals or permits necessary to begin

physical construction and either has (1) begun a continuous on-site physical construction program; or (2) entered into contractual obligationa - which cannot be cancelled or modifind wthout substantial loss - For physical construction of the facility to be completed within a ceasorable elme.

COKrINOOOS MONITORIKG STSTEX means a continuous leak detection and alasm gyetem that is automatic and operates independent of bumen aselatance, that meets industry standards such as thore of onderviters Laboratories (OL). and that is approved by the DIRsCror.

DIESE OI means any grade of distillate ofl commonly referred to as diesel which is utilized for the purpose of vebicle propulston.

DIRECTOR means the Director of the Department of Envifonmental Management of his/ber designee.

Any documents of reports required to be submitted to the DIRsCIOR by these zegulations should be sent to: Chief, Division of Hater Resources, R.I. Department of Envifonmental Management, is Devis Street, Providence, RI 02908.

DRI SEASON means a seasonal time perlod when the groundwater table is at its lowest usually occurring during the months of May-December. Specific dates will be determined on a yearly basis by the DIRscror.

EXISTIHG FACILITY means a facility which is in full operation or at which "substantial construction" has been inftiated on-site or at which construction on any modification has commenced prior to the effective date of tbese regulations.

FACIIITY means all contiguous land, structures, facility components and other appurtenances that form a district geographic unit and at which petroleum produces of hazardous materials are stored in underground storage tanks.

FACIIIHI COMPONENY means any underground tank and/OF associated pipes, pumps, leak monitoring systems, catbodic protection systems, vaults, fixed containers or appuztenant stzuctures, otherwise relerred to as faclitty components, used or designed to be used for the storage, transmission. or dispensing of petroleum products and bazardous materials and serving institutions or industilal, commercial, agriculeural or governmental operations or otber uses not precluded by the provistons of section 5 of these regulations. 
GASOLIKE means a petroleum distillate, of blends of petrolem dist 1 llates, baving a Reid vapor pressure of 7 pounds per sguase lnch absolute $(48.3 \mathrm{k} \mathrm{Pa}$ of greater and used, for example, for the purposes of rebicle propulsion.

Geovipwatzk means water in the saturated zone beneatb the ground surface, and includes all underground waters of wheteres nature.

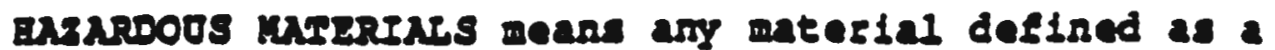
"basardous subotance" by section 101(14) of the Couprebensive Eariromental Response, Compensation, and L1ab111ty het of 1980 (42 USC 9605), as sunded (see Appond1x M. Ensardous meertals sbell aleo lnclude any neterial deflacd as a "bazazdous weste" purauant to the Bhode Island Eazardous Haste Managemeat het of 1978, as well as ang of the following materials:

\section{Acetore \\ Ethanol \\ Ethyleae oxide \\ netbanol \\ Metby lene Chloside \\ perchloroethylene}

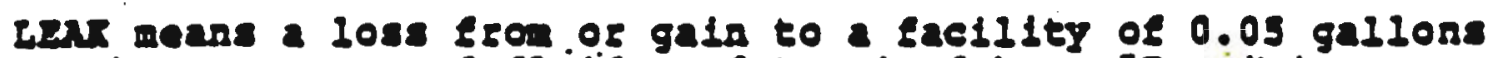
per hous or more of livid as determined by a orgecision Test". Fisual lappection, a contlauous monitoring ratem, inichtory control, of othes appropilate means, and shall be considered a relesse from a Eachlity.

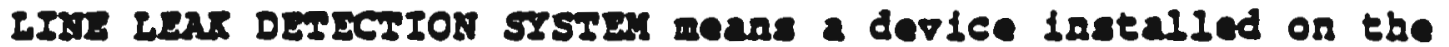
discharge stde of the pump which is capable of intergupting product flow if there is a leak greater tars or equal to 3 gallons pes bous.

LOCN FIR CIEP means the person gesponaible for the adinistration and difection of a. It de department in a fize distelet of manicipality. Including a flie administrator or chles or that person's designee.

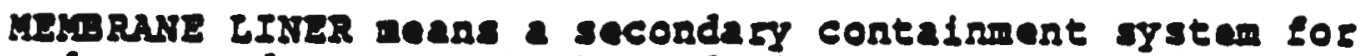
underground storage tanks and plplag constructed from a membrane shect mater1al.

MODIIICATION means ar addtion to an existing factlity of soplacument, restoration. refuzblshnent or zenovation which: 1ncreases or decreased the in-place storage capact of a lacility: alters the pbysical configurationg alters the destgn and/or specisteations of factlity compononts: or impaifs of affects the paysical integrity of a factiley of its monttoring aystoms.

Neif FACILIYY means a Eac1Ilty which was not yot in operation and at which "substantial consteruction" had not yet begur as of the effective date of these regulations. 
NEPA CODE number 30 means the National Fife Protection Association publication number 30 entitled, "Flammable and Combustible ifguids Code". (1984).

NFPA CODE number 329 means the Nationel Pife Protection Association publication number 329 entitled, "Ondergfound leakage of Fiammable and Combustible Iiguids", (1983).

wo. 1 ror OII means a distillate o1l, commonly referzed to as kerosene, range oil, or fet propulation fuel (Jp-l).

wo. 1-D PoEL OII means a dist11late o1l, commenly referzed to as light diesel o11.

No. 2 FoEL OII means a distillate oll, commoniy seferred to as bone beating oll.

No. 2-D FOEL OII means a distillate o1l, commonly referred to as medium diesel o11.

NO. 4 FOEL OIL mans a distillate O1I blend of No. 2 and No. 6 Euel 011.

No. 5 gUEr OII means a distillate ofl blend of Mo. 4 and No. 6 fuel oil.

NO. 6 FOEL OII means a distillate ofl, commonly referzed to as Bunker-C or residual fuel.

OBSERVATION WELL means a cased well that intercepts the water table and can be used to detect the presence of groundwater contamination.

OR-SITE means the same or geographically contiguous property which may be divided by public or private right-of-way, provided the entrance and exit between the preperties is at a cross-roads intersectlon, and access is by crossing as opposed to going along, the right-ok-way. Non-contiguous properties owned by the same person but connected by a flght-of-way which be contzols and to which the public does not have access, is also considered on-site property.

OPERATE A FACIIITY means to maintain petroleum product(s) or hazardous material(s) in underground storage tanks at a facility for purposes of storage, use or sale.

ORERATOR means the person in contzol of of having responsibility for the dally operation of a facility.

OWnER means the person who bolds title to or lawsul possession of a factitity or part of a facility.

PERSON means an indipidual, tzust, flem, foint stock company, corporation (including quasi-government corporation), partaership, association, syndicate, 


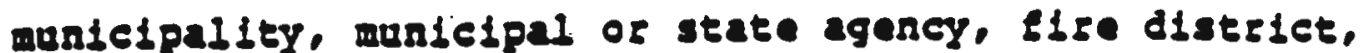
club, non-proftt agency or any. subdiviston. commisston, depaztinent, bureau, agency of department of state of Federal goverment (1ncluding guast-government corporation) or of and laterstate body.

persoretur propoces lacludes:

$$
\begin{aligned}
& \text { - Essolino } \\
& \text { - Fuel O11 (No. } 1 \text { and 2) } \\
& \text { - Dlesel O\$1 (ko. I-D and 2-D) } \\
& \text { - Naste } 011 \\
& \text { - Gasobol }
\end{aligned}
$$

pracision IEst mean a test able to determine whotber of not an underground storage tank is leaking as deflaed by MPRA 329. "Jnderground Leakage of Flammable and Combust 1 ble ifgulds". Th1s test mast be capable of accurately detecting a tank of plping leak as mall as 0.05 gallons per hous, adfusted for al vartables. The test aethod wust be approved by the DIRucior neter to nas, and must be conducted by persons who have domonstrated capablitty to properly conduct the test as determbind by the DIRECTOR.

RNEASE means any spl111ng, leak1ng, entetsng, dlschargtng. cecaping. lexching or disposing from an underground storage tank lato groundwatef, suzface watez or subsusface solls.

RMOVE FROM SERVICE Dears to cease to operate a factlity copponent.

SPII means a loss of petzoleum product of hezardous matertal in a mannes otber than a leak, occurstag on the property where a tacility do in operation, and such that the product or material is Iikely to enter grousd water oz surface water; and shall be constdered a release from a sact116y.

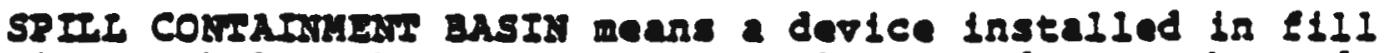
pipe manholes that prevents petroleum product or bazardous material spills $\mathrm{from}$ leaching $1 \mathrm{sto}$ the soll and grounowater.

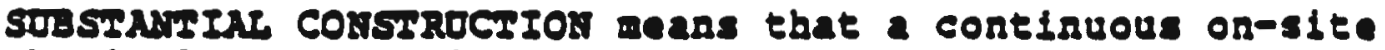
plysicul construction progran has progressed to a polnt where at leart 258 of the total project is completed of whleh represents an expendituze of woze than 25 of tbe total cost of the profect for materials which are at the stte.

SUBSTANTIAL KODIEICAEION Of a Eac1lity means modification to a facility, facility component or now faciliey plans tar would conflict with information provided to the DIRECHOR in application for a certificate of zegistration or that would be expected to resule la roduced performance of a facility component as it relates to leak prevention or dotection. such modification lacludes but is not liaited to: 
(1) The installation of tanks not recorded on the application for a certificate of registration for the eacility:

(2) Ondezground storage tank repair, relining or replacement:

(3) Por petzoleum products, changes in type of product stored (gasoldne, No. I Fuel 011. No. 2 Euel Oll, No. 1-Diesel O11. No. 2-D Diesel 011, Waste O11, or Gasobol):

(4) For hazardous materials, changes in the material storeds

(3) For a wow Pacility, alterations to the site plan;

(6) Changes in the design or specifications of a facility corrosion protection systems

(7) Changes in the design, spectelcations or location of Eacility leak monitoring equipment.

SURPAC MATER means a body of water whose top surface is exposed to the atmosphere and includes all vaters of the territorial sea, tidewaters, all inland waters of any rifer, stream, brook, pond or lake and wetlands.

ONDERGROUND means 10 percent or more of the rolume of tac1lity components (storage tanks and piping) is buried in. the ground.

THDERGROOND. STORAGE TANK means any one or combination of tanks (including underground pipes connected tbereto) wbicb is used to contain an accumulation of petzoleum product or hazardous material, and the volume of which (including the volume of tbe underground pipes connected theretol is 10 percent or more beneath the surface of the ground.

VAOLI means a secondary enclosure which houses an underground storage tank, contains any leaks from the tank, and provides protection from corrosive soils.

WASTE OIL means used or spent ofl of any kind, including but not Iinfted to those olls from automotive, industrial, arlation and other source categories.

\section{SECTION I. PACITITE RECISTRATION}

(a) The operator of a facility shall apply for and obtain a certificate of registration from the DIRICTOR in accordance with tbese regulations and pursuant to the following schedule:

(1) Nev Facilities, shall apply for and obeain a certificate of registration before commencing construction. 
(2) Extatine factilitis, lncluding facilities where modifications were commenced pefor to October 9 , 1984 (the effective date of the Emergency

Regulations for Onderground storage Pacilities), ohall apply for a certifleate of registration by Apr11 9, 1985 .

(b) in appliestion for a certificate of gegistration shald be subitted on form provided by the DIRECTOR, and shall lnclude but not be linited to the following:

\section{(1) Preveritites}

(1). A set of detalled angineering plans and spectelcations of the profect, includiag operation and mintenance requigements. that have been certifled by a zegistered professional engtreer.

(11) A stte plan foeluding all of the information listed below:

(A) Proposed location of all tanks, plping, and dispansing pumps.

(B) Proposed location(s) of on-site observation wells.

(C) Location of all private and public vater supply welis witbin 1,000 feet of the facility location.

(D) Proposed butlding locations

(z) Legal boundartes

(I) Bozth Afrow

(G) Deseription of and specifications for all proposed leak monitoring systems.

(iv) S1ze, constzuction material of tasks, and type of material storad.

(2) Extating Factliting

(1) The results of any testing conducted on all tanks and associated piping (if available).

(11) Stze, age, and construction material of tanks, type of material stored, and existence of tank and piping protsction derices. 
(1ii) A site plan including all of the information listed below:

(A) Location of all tanks, piping, and dispenaing pumps.

(B) Location of existing, on-site monttoring wells.

(C) Bullding locations

(D) Legal boundazies

(E) Hozth AEzow

(F) Descziption of and speciflcations for al l leak monitoring system in operation.

(1V) $A$ deseription of ald spills and leaka that bare occursed at the site.

(c) All certiflcates of registration issued under the - Energency Regulatione for onderground storage Fecilities osed for petrolem produets and Barardous Materials", adopted 9 October, 1984, sball ramain in full force and effect provided the onner and operator submit a witten certification in accordance witb section 16 of these regulations.

(d) Fallure to obtain a certificate of ragistration in accordance witb these regulations shall constitute a violation of these regulations and may subject the operator to penalties referenced in Section 20 . penalties. An onner or operator of a Faclilty that has falled to obtain a certificate of registration in accordance with these regulations shall immediately implement facility closure procedures in accordance with section is of these zegulations and obtain a certificate of closure.

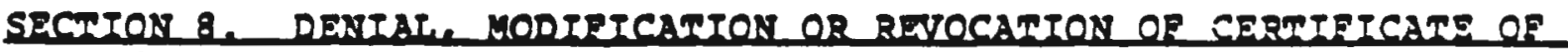
BEGTSTRATION

(a) The DIRECTOR may, after at least twenty days notice in witing to the person or persons affected, and after a heasing, if requested by the affected person or persons, deny, modify or revoke a certiflcate of registration for cause including, but not linited to:

(1) Information indicating that the storage, location and/or opezating procedures pose an imnediate threat to public bealth or the envigonment;

(2) The Information submitted by the application was incomplete, false or misleading: 
(3) Clfcumstances on which the certiflcate was based bave materially and substantially changed since the eertilicate was issued.

(b) Tpon the dental of serocation of the certiflcate of reglstration the owner or operator sball imediately 1.plement factity closure procedures la accordance with section 15 of these regulatione and obtala a certifleate of closure.

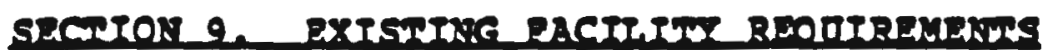

(a) 11 underground storage tanks at exlsting fackl1ties that are giulpped witb renote pumps shall be fltted with a line leak detection sysem witblo two (2) yeass of the effective date of these rogulations.

(b) $\mathrm{Nl}$ underground storage tanks at existing facilities aball be fitted with spill containment basing around all fill pipes witbla two (2) years of the effective date of these regulattons.

(c) Al existing factlity copponents (underground storage tanks and plping) which do not conform to the new faciltty gequifements listed in saction 10 aball weet the following sogutranents:

(1) MI exlating facility components (tanks and plping) that were lastalled on or after Januag 1. 1965 shall be preclston tested vithlo two (2) years of the effretive date of these regulations.

(11) MI exlating facility componentes (tanks and piping) that were installed priog to Januasy 1. 1965 shall be precision tested witbin one (1) Yeas of the effectire date of tbese reguiations, and annualiy thereaster.

(111) All extstigg Eacility components (undeggzound storage takks and plping) for wbich the date of Initial inataliation is known and restelable and that do not meet the ncw Eacility requifements listed in section 10 aball comply with one (I) of the following:

(A) The underground storage tank (s) and plpisg shall be precision tested in accordance with the following schedule (yoars after intelal instaliation):

$$
\text { 5. 8, 11, } 13
$$

Precision testing shald be conducted on an annual basis for the undergzound 
storage tanks and piping z ter 13 years of the date of tank inata: ation.

(B) A contiauous monttoring ag iten or syoton compatible with tl : product/matertal stored as i approved by the DIRsCIOR sball be inst illed witbin two (2) years of the effer ifve date of these zegulations the une :Eground storage tank(s) and pipinc sball be

- preciaion teated at five: lar latervals following the installatior of the nonitoring dovices and thi underground storage tank(s) sball be inclsion tested bleanially after $2 \hat{l}$ yeass of the date of taak lastallation.

(d) AI existing fac1IIty underground atorage tanks for which tbe dates of Installation are unkn in or unveriflable sball be precision tested $w:$ :hin one (1) year of the effective date of tbese regu: ittons, and annually thereafter.

(e. Results of all preclston tests requiged in ibls section sball be aubitted to the DIRscrok within is calendas days of the date of test completions or in accordance with Section 14. Leak Response.

(f) Written verification of compliance with I ites (a), (b), and $(C)(111)(B)$ of this section sball be jubmitted to the Difector within is calendar days of : istaliation of the requised equipment.

(g) AII continuous monitoring gystems shall be teated by the operator on a montbly basis to easure that they are operating effectively. Records of such tests shald be malntained in accordance with Section 13, Maintaining Records.

(b) The operator of an existing facility may, in accordance witb section 18 of these regulations, seex a variance so that existing facility components (unierground storage tanks and plping) nay be regulated in accordance with new Eacility requirements of Section 10 of these regulations.

(11) Reserved for existing facblity requizamer is for underground storage tanks used for storji; No. 2 fuel o11.1

SECUTON 10. NER EACIT TUY REOUIREMENUS

(a) All facility components and all celated 6 uipment shall be Installed, used, and maintained accore ng to the manufacturers specifleations and instruct ons and NEPA
Code 30 . 
(b) Alf aw tacllity componeats (underground storage tanks and plpiag) shall be precision tested upon completion of the Installation, but beforo opezation. Results of the precision test shill be submitted to the DIRzCTOR with 13 calendar days of test completion or in accordance with section 14, Leak Response.

(c) $M 1$ underground storage tanks at new Eac1lities shall be elteed with spl11 containment basins azound all fill pipas.

(d) Bnderaround sterage ranke

(1) Ill atw underground storage tanks shall be constructed with materials. that are compatible with the stored material or product, sultable for the expocted external onvironment, and aect the

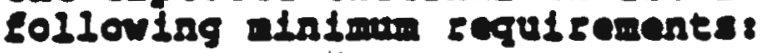

(1) Stenl ranks - Taderwrtters Laboratorles (0.L.) Ilsted standard 58 steel tank or other nat lonal laboratory standard approved by the DIRECroR.

(1i) Stberiase ranke - Oaderwetters Labozatozies (0.L.) Llated Standard 1316 Elberglass tank or otber natlonal laboratory standard approved by the DIRECIOR.

(2) Alf tanks shalf bave ong-guarter lach steel weas plates centered under all opentags with minimum dimensions of $8^{\circ} \times 8^{\circ}$.

(3) 111 tanks shall bare a subuergod 1111 tube.

(4) AIl tarks shell be factory tosted at a minfmum of fire pounds per square inch gauge and guaranteed tight by the manufactures.

(c) Plpe, Plttings and Pumping Systams

(1) Il aw factlfties sball bave piping meeting or exceeding the following requizements:

(1) Cathodically protected schedul 40 steel pipe.

(1i) Normetallic pipe listed by O.L. Or other Rational laboratory appeored by the DIRECIOR.

(2) Alt delivery pipling systema using a zomote pump shall be equipped witb a line leak detection sistame 
(3) All metallic delivery piping shall employ swing joints at all changes in dizection.

(1) All delivery systems employing a suction pumping rystem shall use one only check valve in any eucetion line.

(5) All delivery systems shall be pressure tested at 150s of the working capacity (minimum of 50 pounds per square lach gauge) and pressure shall be maintained during the test for a minimum of one bour. Testing shall be conducted prior to backfilling of the delivery syatem pipe network.

(6) All piping shall be compatible with all of the products transported and tank materlals used at the Eac111ty.

(7) The terminus of remote piping systems shall bare an emergency shutoff valive at the base of the dispensing unit to shut off product flow in the erent that the dispensing pedestal is displaced or exposed.

(E) Coszosion Protection

(1) All tanks and thelg piplng systems shall be protected by one of the following:

(1) $A$ properly englneered, Installed and maintalned catbodic protection system in accordance with recognized standards, such as $0 . E$. of Canada OLC $603.1-B-1982$. - Standard for Galvanic Corrosion Protection Syrtems for steel underground Tanks for Flammable and Combustible Llquids", Steel Tank Institute Standard No. STI-P3, - Specificatior for STI-P3 System of Corzosion protection of onderground steel Storage Tanks - 1983", and National Association of Corrosion Engineers Standard RP-01-69 (1983 Rep.) Recommended Practice - Control of Exeermal Corrosion of Onderground or Submerged Metallic piping Systems".

(11) Corrosion resistant materials such as tiberglass reinforced plastic, or fiberglass relnforced plastic coatings, or equivalent approred system as listed by the American Society for Testing and Materiais (ASTIY) or other national labozatory approved by the DIRECTOR. 
(g) All new facilities shall comply with ane (1) of the folloving zequiforents:

(1) Installation of a continuous monstoring system compatble with the product/material stored and approved by the DIREcror. and pracision testing. of the facility (tanks and plping) at itro yae latervis until a tak age (gears after infelal lantaldation) of twonty years and then biennialiy thoreafter. Results of procision testiag aball be anbitted in witting to the DIascror within is enlendar dags of the complotion of the test, or in cecordnee with Section it. Leak Repponsi. Conthuous monttortag grotem shall be teated nothly in accordance with section $g(g)$.

(2) Installation of doublewalled takks witb a continuous laterstitial nonitoring raten and a accondary contaloment plplag ryatem. The tarka and plping stall be listed by a national laboratorg that $1 \mathrm{~s}$ approved by the DIRECrOR.

(3) One of the followlag secondary contalnent rystems approvad by the DIRSCIOR, with a contlnuous monttoring rysten lnside the contalnment systems

\section{(1) Vaule}

(A) The vaule abal be a conthuous atructure which 19 impervious to water and the stored product.

(8) The l1005 shall be aloped at least 1/8" pes linest loot.

(C) Al openings (1.0. manboles, E111 plpes. ete.l shall be watertight.

(D) The tanks shall be 1rstelled and properly ancbored in the vault is a anner conalstent with acceptablo ogglneertag practices and standards for asoty.

\section{(11) Kambrape Iider}

(A) The mabrane liger shall bave a permeation rate no greater than 0.25 ouncer pes square loot per 24-bours.

(B) The permeation rate shall be the insiman rate of transport ores time of the product stored. 
(C) The volume swell of the lines

following 24-bours of immersion in the stored product shall not exceed 3 percent of tbe ortginal membrane thickaess.

(D) The mextmum change in elongation of the Ilner following 24-hours of trmerstor in the stored product shall not exceed 9 percent.

(8) The liacr Shore D hardness after 24-bours of Imeraton is the product stored shall be within 5 polnts of the ortgtaal bardness.

(E) The rate of transport through the Ilner material of the product stored aball not be greater thas 6 percent by welght.

(G) The solubility of the Ilner shall not exceed 0.1 percent by welght in a 24-hour period.

(E) The Ifact seam strength shall be cqual to the tensile strength of the parent material.

(I) All teating of material shall be performed usting accepted engineering practices approred by the DIRECTOR fOr materials tested. The IIner shall be Installed under the superviston of the manufacturer of the secondary containnent membrane liner system.

(J) The tanks shal be Installed and properly anchored in a manner consistent with acceptable engineering practices and standards for safety.

(111) Approved Equal Secondary Containment System - any containment rystem that can be proven to be equivalent to the above sections $(1,11$,$) may be used subject to the approval$ of the DIRECTOR.

(b) obserpation pelis

(1) Any new facility that the DIRECTOR determines to be located in an aren where a leak could affect groundwater that my be used for present of future drinking purposes, in a watershed of present or 
future public water supply, or in an enpironmentally seasitive area shall have a minimun of three (3) observation vells meeting tbe spectfleations givea below. Eactors to be constdered by the DIRECrOR in making this determination will laciude but not be limited to groundwates claselfleatlons developed by the BIDECIOR of the O.S. Environmental Protection Agency (EPA), the location of sole source aquifers dealgnated by the BPA, groundvater studies such as those of the 0.S. Goological surver and pater Rasousces Bonsd, the location of senstefite or protected areas deslganted by local goveraments, and the location of public driaking vater supplies.

(2) Molls shall be located is such a manner as to triangulate the factlity. The location of the observation wells and or the gequisement of addtelonal wells is subject to the apptoval of the DIRECTOR Observation wells shall be corstructed as describeds

(1) The screen portion of the wells shell extend a intmu of 5 leet below the groundwater artace for the arerage water table elevat10r at the stte during the dre nnop. The sercen sball be open to the weer sugsace at all times. The maximum well dopth shall be thisty loet unless otberitse spectiled by the DIRECIOR.

(11) The sereen shall be of surelelent length to compensate lor sesconal flucturtions in the veter table.

(111) All vel1s shall bave a alofmem Lostde dianetes of two (2) laches and be constructed using a miafmum of schedule 40 ive piplag.

(1v) All wells sball have bottom caps.

(v) All wells shall be gravel packed and grouted.

(vi) There possible the wells shall bave a mounded surtace seat azound the well casing and an abore grade locklag security cover. If the well must be Elatahed at ground level, a tamper resistant cover that prevents surface zunots from enterting the wells shall be used.

(1) Reserved for new Eac1lity requirements for underground storage tanks uad for storing No. 2 fuel o11.l 
(a) No subetantial modification may be made to an existing or now tacility for which an application for a certiflcrte of registration has been filed or for which a certificate of registration has been obtained without prior written notification to and approval by the DIRECLOR.

(b) Al modification to of replacenent of existing facility or nw facility components abul be made in conformance with the requirements of Section 10, wew Pacility Regut rements.

(c) osed tanks meeting the apecificationo given in section 10. Now Pacility Requigoments, can be lnstalled in an existing or new facility provided:

(1) the used tanks have been inspected and tested by the manufacturers

(11) the used tank has been certified by the manuestures to be reusable for the product to be stored, and

(111) the used tank is given the same warganty by the maufactuges as given to a new tank.

(d) Onderground storage tanks can be repaired or relined once provideds

(1) the DIRECIOR has approved the repalt or relining metbods

(11) the tank is precision tested following tank repairs or reliniag, and no leaks are detected; and

(111) the method for repajging of relining is compatible with the product or material stored.

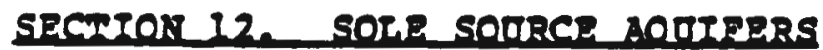

(a) Existing facilities located in sole source aquifers, as designated by the O.S. Envisonmental Protection Agency, ahali be subject to addttional monitoring and testing requirements as determined by the DIRECiOs to be nocessary tor aquifer protection.

SECRTON 13. MATXEATMING RECOROS

(a) All owners or operators of new and existing facilities ahall maintais on the facility premises records of: 
(1) all data uaed to complete tbe application tor the certilicate.

(2) all calibration and malntensace pertormed.

(3) stelp chart. electronie recall dovice and/or pand zocosdings for any contlauous monitoring lactinentation.

(4) ang nonitorlag, leak detcetion gytem, lnventory contsol gistan and/or tank testing.

(3) nonthly tests of contluuous nonjtoring gretem as reguled ta scetion 9 and 10.

(6) a dally laveatory of the product or material atored. Ineludiag the following atalmon Laformst 100 s

(1) a gecord of al Laflows

(11) a record of al outslows:

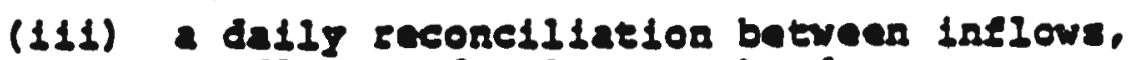
outslows and rolume on hand?

(1V) writen del1y entries of ary unuaund occugzonces that ighe affect the lnelow. outelow or polume on bands

(v) Written entiles explatalag in detall any adjuatements to the recorda.

If such record keeplag indlcates a diserepancy of It or more of total polume stored in any tank. as a minimue, on a weekly basis, the owner or operator shall roport such discrepancy in accordance with suction 14, Leak and Sp111 Response.

(b) Recozds of the information listed in part (a) shall be malntained for a period of three (3) years from the date they are made. or for such longer periods as ragulfed by the DIRECIOR in as unsesolped enforcenent action.

(c) The facility ownes of opezator mast make ava 1 lable to the DIRECTOR, upon scguest. all racosds which the DIRECIOR geels pertinent to the cnsorcement of these Eules and regulations.

(d) Section (13) (a) (6) does not apply to tanks used for storing fuel ol I (No. I, I-D, or 2 ) on stes for consumptive use, of to takks used for storing waste 011. 
(a) Any owner of operator who is awaze of or has cause to suspect a leak or spill from a lacility shall report it immatinely to the local 1150 chies and the DIRsCrOR. The owner or operator shall flie a wilten report with the DIRecior within seven (7) calendar days of the time the leak of spill was flrat discovered and shall lnelude the known or presumed cause or the leak or apll1. results of any tests, iaventories, monttoring or inspection that Indicate a leak or aplil, the known of eatimated quantity and type of product or material leaked or ept-1ed, and the length of time the leak of apll1 was occursing.

(b) It the DIRECIOR's request, the owner shall argange to precision test any tacility component (tank and piping) which the DIRECIOR has good cause to suspoct is loaking within 24-hours of the request. If no leak is

detected, a witter report of test results shall be subnitted to the DIRECIOR within 15 calendar dnys of teat conpletion. A detected leak shall be roported in accordance with part (a) of this section.

(c) All leaking facility components mast bo apted withid . 24 bours of discorery of the leak, and aball remain appy until such tine that the leaking components are repeired or replaced in accordance with the

requifoments of section 10 and section 11 , or until the. Eacility component is permanenty closed in accordance wib seceton 15.

(d) The owner or operator of a factlity tbat is located on property at which a leak or splll has occursed or at whlch the DIRECIOR has good cause to suspect that a leak or splil bas occuszed sball install observation wells on the property at the DIRECIOR's requese. The number, construction and placonent of these wells shall be approved by the DIRECIOR.

SECTION 15. CROSTRE-

(a) Abandonment of underground storage tanks is probibited.

(b) Temporary Closure - The owner or operator of underground storage tanks that are removed from service for 180 days or less shall:

(1) cap and secure against tampering all E111 11ses, gauge operiags and punp suction lines; 
(2) keep the reat lines open;

(3) malntain rocozds regazding:

(1) underground storage tank location and size:

(11) date on which underground storage tanks were taken out of operation; and

(111) the procedures used to maistain the Pacility ta a safe condition.

(c) The DIRECIOR way extend the pertod of temporary closure of an underground storage tank or tanks to more than 180 days 105 good cause. Potitions for extension must demonstrate good cause and be liled with the DIRECrOR within 60 caleadar days following the date the underground storage tank (s) is/are tomporarily removed Ezon service.

(d) Permaneat Closure - All ovates or operators that remove any underground storage tank from service for more tban 180 days and bave not been granted an extension of temporary Closure by the DIRECIOR or who bave abandoned any tank (s) shajls

(1) Comply witb the procedures for clostag the underground storage tank (a) in accordance wtth part (a) of this section;

(2) Apply to the DIRECTOR LOr a ceft1flcate of elosure at least 10 days pFior to the date the tank is to be permanenty gamoved fzom service in accordance with the provistons of this sectlon. Such applieation sball include:

(A) The date the tank is to be permanenty rowoved from sestice in accordance with the procedures outlined bereins

(B) The age of the tank to be permanenty zemored tron service:

(C) The type of substance of material that was stored in the tank;

(D) The closure procedures to be lollowed;

(E) The size, type and location of the task if it is to 5 emain is the ground:

(2) The date of tank excapation if the tank is to be zemoved fzom the ground:

(G) Appropriate documentation substantiating compliance with the closure procedures outlined in this section; and 
(3) Obtain from the DIRECTOR a certificate of closure.

(e) As owner or operator that removes any underground storage tank(s) from service for more than 180 days and has not been granted an extension of temporary closure for more than 180 days by the DIRECTOR or who has abandoned any tank(s) shall eltber:

(1) Renove underground tank(s) and related sacility components in accordance with pact (f) (l) of this section; of

(2) Allow the underground tank(s) and related facility components to remain in the ground, providing that the requirements listed under part (f) (2) of tbis section are met.

\section{(E) Permanent closure procedures:}

(1) The owner or operator may permanently close underground storage tanka by removing the tanks and related facility components provided that:

(1) all product is remored from the taink (s) and connecting $11 \Omega e s$;

(11) the tank is cleaned to remore any residue or material in the tark, and such restdue or material is disposed of in accordance with applicable state and local laws and regulations;

(iii) the gaseous vapors are released at the ste in a safe manner approved by the DIRECTOR:

(iv) the DIRECTOR is given at least seventy-two (72) houss notice of the time of excavation of the underground components so that the site may be inspected for the presence of pollutants:

(v) upon zequest of the DIRECTOR, stzuctural supports necessafy to ensure that the excavated area can be salely and thoroughly inspected for the presence of poliutants are installed;

(vi) before disposal, a sufficlent number of holes of openings shall be made in the tank(s) so as to render the tank(s) unfit for further use. No cutting torch or other flame of spark producing equipment shall be used until the tank has completely purged or otherwise rendezed safe: 
(Vi1) any excavated contaminated soil or debris is disposed of in accordance with approprlate state and Federal laws and regulations.

(2) The orner or operator of a Facility may perminentiy close undezground stozage tanks by Ilowlag the tank(s) and/or associated factilty components to remain in the ground provided that:

(1) a Procision Test is conducted on the tank (s) and associated piping of the Facility, the results are furalsbed to the DIRECIOR and the test zeveals no leaks:

(11) all product from the tank(s) and from all connceting lines is remored:

(111) the tank is cleaned to remove any restdue or material in tbe tank, and such restdue or material is disposed of in accordance with applicable state and Local laws and zogulations:

(1v) all 111, gauge, pump and vent lines are disconnceted and all inlets and outlets are capped or plugged; and

(v) all tanks are filled completely with an laert solid material and all remaining underground plping assoclated with the tank (s) are capped and secured against tampering.

(g) If the precision rest required in accosdance with part (E) (2) (1) of this Section zereals leak (s) in the tank(s) or associated piping, the DIRECTOR shall determine which, if any, components of the Facility sball be remored to investigate the extent of envifoimental damage.

(b) Any owner or operator of abandoned undergzound storage tanks shall within six months from the effective date of these regulations close the tanks in accordance with the permanent closure requigements of this section.

(1) Certificate of closure

In accordance with part (d) of this section, the owner or operator of a tank to be permanently remored from service shall apoly to the DIRECTOR for a certificate of closure and shall provide the DIRECTOR with appropriate documentation substantiating compliance with these regulations. Such documentation shall include but not be limited to the results of precision 
tests requized. The DIRECTOR shall, baser upon a 71 review of the application and other infor: ation, determine whether the gacility is in comp. iance with these regulations, and shall:

(1) Issue a certificate of closure; or

(2) require that certain deficiencies be corrected pitor to the issuance of a certifica e of closure and witbin a specifled period of till ; or

(3) Issue a certificate of closure witb onditions such as but not limited to monttorin. reporting or site restoration requirements, pr vided, howerer, that no conditional certifi ate of closure can be transferred to a new wher or operator without conforming with the reguirements of Section 17, Transfer of Certifica es of Registration and Cloaure.

(j) Any owner or operator that has not applie for or obtained a certificate of closure in acco dance with this section shall be in violation of the e regulations and subject to tbe peralties referenced 1 .. Section 20 of tbese regulations.

(k) All certiflcates of closure issued under he "Emergency Regulations for onderground storage Facll ties osed for Petroleum Products and Bazardous Material " adopted 9 october, 1984 shall remain in full force nd effect provided the owner and operator submit a litten certification in accordance with section . 6 of these regulations.

\section{SECTION 16. SIGNATORIES TO REGISTRATION AND CLOS. RE} APPIICATIONS

(a) All applications for a certificate of reg.stzation and for a certificate of closure sball be sic ed as follows:

(1) Por a corporation: by a responsible corporate officer. For the purpose of this se tion, a responsible corporate officer means:

(1) a president, secretary, treasur 5 , or vice-president of the corporati n in charge of a peincipal business functio, or any other person who performs simil 5 policy or decision making functions for te corporation, or

(11) the manager of one or more manu acturing, production or operating facilit es employing more than 250 persons or haviag gross annual sales or expenditures exceeding $\$ 21$ million (in second-quarter 1980 dollars if authority 
to sign documents has been assigned of delegated to the manager is accordance witb corporate procedures.

Noter DEX does not requize speciflc assignments or delegations of authority to resporsible corporate offlcers identified in $16(\mathrm{a})(1)(1)$. The Dax vili presume that these responsible corporate orficers have the reguisite autbority to sign permit applications urless the corporation has notificd the DIRICHOR to the contrasy. Corporate procedures governing autbority to sign permit applications my provide for useignment of delegation to applieable copporate postelons under $16(a)(1)(11)$ sather than to specitic individuals.

(2) Por a partacrsbip or sole propictetorshipg by a general pastner or the proprietor, respectively:

(3) Por a munieipality, state, Pederal, or otber public agency by eltber a principal executive offlcer or ranking elected offlelal. For purposes of this section, a principal exceutive officer of - Faderal agency includes:

(1) The chice executive offices of the agency. of
(11) a sentor executive officer having responstbility for the orerall operations of a pincipal geographic unte of the agency (e.g.. Regional Adninistzators of EPA).

(4) For a militasy 1nstallation: by the isstallation commander of a sank of 06 of highej, if the Installation amploys more than 250 persons and autbority to sign permit applications bas been assigned of delegated to the Installation Comander in accordance with applicable Department of Defense (DOD) procedures. Is an Inataliation Commander does not meet these requirements. the permit application must be signed by a supezior officer who meets the requizements.

In addition, where a tenast is present on the. Installation and bas autbortey or responsibility 05 any aspect of tbe regulated actioity. the renant commandes (zank of 06 or bigher) must also ign the application. The Tenart Commander must also employ more than 250 persons and bave been assigned or delegated authority to sign permit applications is accordance witb applicabie DOD procedures. Again. if tbe renant Commander does not meet these requirements. the permit application must be signed by a superior offices meeting the requirements. 
(b) Reports. All reports reguired by these regulations and otber information requested by the Director shall.be signed by a person described in paragraph (a) of this section, of by. a duly authorized representative of that person. A person is a duly authorized representative only if:

(1) The authogization is made in witing by a persen described in paragraph (a) of this section:

(2) Th authorization specifies either an individual or a posttion having responsibility for overall operation of the regulated facility or activity such as the position of plant manager, operator of a well or a well fleld, superintendent, or position of equivalent responsibility. (A duly autborized representative may thus be ither a named individual or any individual occupying a named position), and

(3) The witten authorization is submitted to the DIRECIOR.

(c) Changes to authorization. If an authorization under paragraph (b) of this section is no longer accurate because a different individual or position has responsibility for the overall operation of the facilizy, a new authorization satisfying the requizements of paragraph (b) of tbis section must be submitted to the DIRECIOR prior to or together with any reports, information, or applications to be signed by an authorized representative.

(d) Certification. Any person signing a document under paragraph (a) or (b) of this section shall make the following certilication:

I certify under penalty of law that this document and all attachments were prepared under my direction or supervision in accordance with a system designed to assuge that qualified personnel properly gather and evaluate the information submitted. Based on my inquiry of the person or persons who manage tbe system, of those persons directly responsible for gathering the information, the information submitted is, to be the best of my knowledge and belief, true, accurate, and complete. I am aware that there are significant penalties for submitting false information. including the possibility of fine and inprisonment for knowing violations.

(e) All owners and operators who obtained a certificate of registration or a certiflcate of closure pussuant to the "Energencl Regulations for Underground storage 
Facllities used for Petroleum Products and gazajdous Materials" shall within 60 days of the effective date of these regulations submit to the DIRECTOR the following signed statement:

I certify under penalty of law that al I information previously submited to the DIRECTOR was prepared under my direction or supervision in accordance with a system designed to assure that gualified personnel properly gather and eraluate the information submitted. gased on my inguiry of the person or persons who manage the system. or those persons directly responsible for gatbering the information, the information submitted is, to be the best of my knowledge and bellef, true, accurate, and complete. I. an aware that there are algnifleant penalties for submitting false information, including the possibility of fine and ingrisonment for knowing violations.

Failuze to subuit the above-signed statement may be cause for the revocation of the certificate of registration or closuze.

SECTION II. TRANSFER OR CERTIRICAMES OP REGISTRATION OR CROSURE

(a) An owner or operator of a facility may transfer the certiflcate of ragistration or of closure to a new owner or operator provided:

(1) The curgent certificate bolder notifies the DIRECIOR in writing by certified mail of the proposed transfer at least thifty (30) days prior to the proposed transfer date" and includes the following information:

(1) Name and address of cugzent gacility;

(11) wame and address of now owners and opesators;

(1i1) Mames and addresses of persons ugon whom legal process can be serped;

(1V) A notafized statement signed by a culy authorized offices or agent of the new owner of operator statirg that he has:

(A) read the orfgial application tor a certiflcate of registration or ciosure and

(B) believes that there has beer no substantial modification in the operations of the gacility since the certiflcate was issued; 0 : 
(C) describes the changes that have occurged since the certificate was issued.

(v) A proposed transfer date on which the new owner will assume the certificate and all accompanying zesponsibility.

(2) The DIRECTOR does not notify the existing certificate holder and the proposed new certiflcate holder, within twenty $(20)$ days of recelpt of notice of proposed transfer, that additional information is needed or of an intent to modify, revoke or revoke and reissue the certificate. If such notice is not received, the transfer is effective on the date specified in tie notice provided to the DIRECIOR pursuant to paragraph (a) (I) (v) of this section.

(3) The existing certificate of closure does not contaln any ongoing conditions in which case the certificate can oniy be transferred upon:

(i) the receipt by DEM of a notarized statement signed by the new owner or operator stating that be agrees to abide by all conditions of the certiflcate; and

(ii) the express witten consent of the DIRECTOR.

\section{SECTION 28. VARIANCES}

(a) Any owner or operator of a facility may submit a written request to the DIRECTOR fOr a variance from some or all provisions of these regulations.

(b) The owner or operator shall have the burden of proving by clear and convincing evidence that a variance should be granted because alternative design or operating standards are substantially equivalent to the regulations and wil have no doverse effect on public health and the environment.

(c) If the DIRECTOR determines that there is widespread public interest or that the rariance request raises major issues that could affect other facilities then the DIRECTOR may schedule a public hearir.g to solicit public comment prior to rendering a decision on the variance request.

(d) The DIRECTOR'S decision to grant or deny a variance shall be in writing and may, as a condition of granting the variance, impose appropriate requirements necessary to protect the public health and envizonment. 
(e) Any pezson affected by the grant or denial of a variance sequest may, in accordance with the Administrative Rules of practice and Procedure for the Department of Envisonmental Management, flle a claim for an adjudicatory hearing to seview the initial decision.

SRCTION 12. SEVBRABIIITY

If any propision of these regulations of the application thereof to any person or clrcumstances is held invalid by a court of competent furlsdiction, the remainder of the rules and regulations shall not be affected thereby. The invalidity of any section or sections or parts of any section or sections shall not affect the validity of the semainder of these rules and regulations.

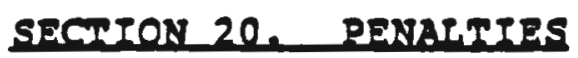

Penalties will be assessed in accordance with Rhode Island. General Laws Chapter 46-12, 42-17.1, and 23-19.1 for any violation of these regulations. 
The foregoing rules and regulations, after due notice and hearing are hereby adopted and filed with the secretary of state, this /f in day of fecil, 1985, to become effective twenty (20) days thereafter, in accordance with the provisions of Chapter 46-12, 42-17, and 42-35 of the General Laws of Rhode Island, 1956, as amended.

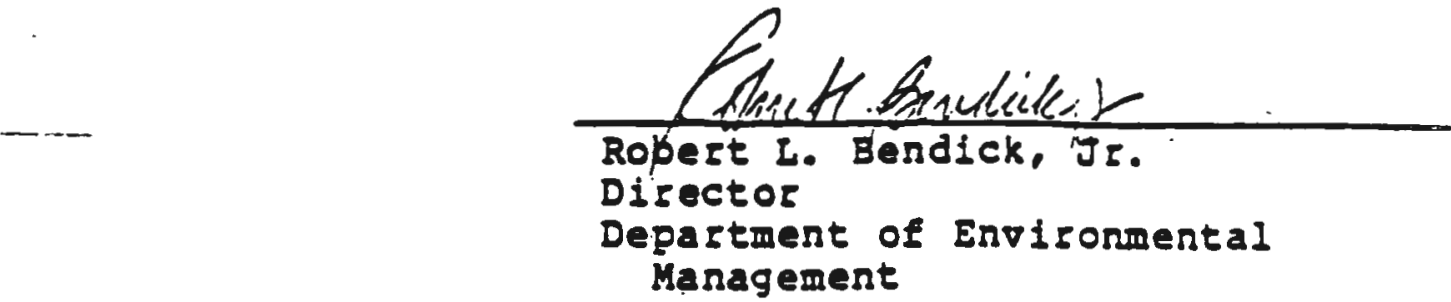

ATIEST A IRRE COPY:

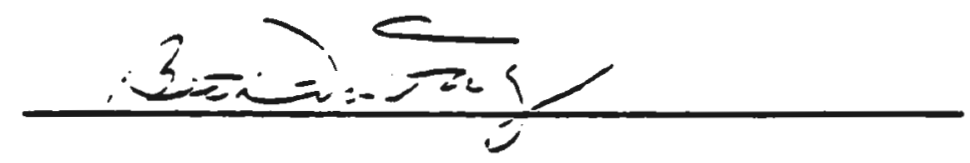


. The foregoing rules and regulatiors are hereby aforoved for Finters whth the secretary of State in accordance with the provisiors of the General Iaws of Rhode Island, 1956, as amended, Chapter 46-j5, spectelcally. Sect1an 42-17.3-2 and the Public Laws of Fhede Isiand, 1978, Chapter 229 and Crapter 46-2.

Date $4-16-85$

Date

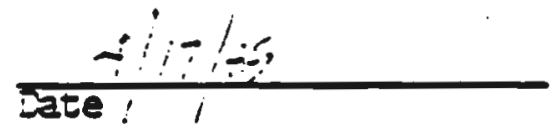

Attest a true cogy.

ENIFONMENTAL STANDARDS BOAFD

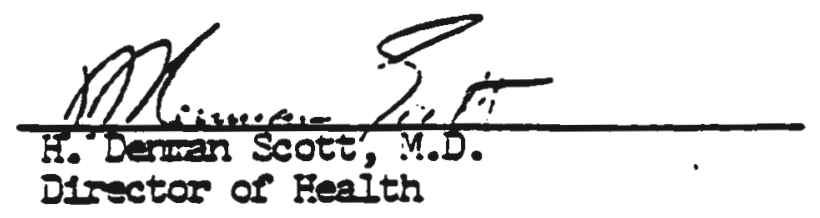

W1ckael Doyle

Disector of Adntristration

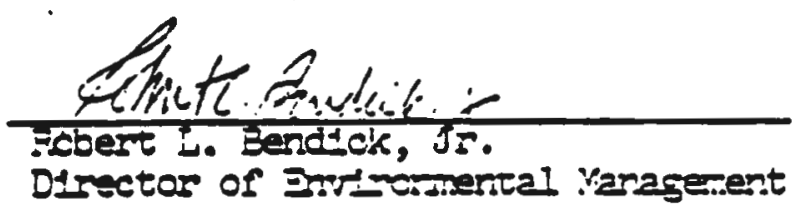

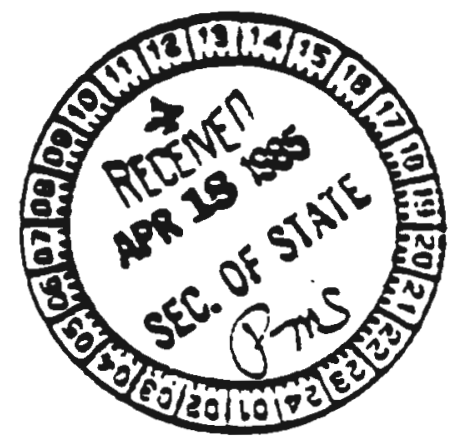


The foregoing rules and regulations are hereby approved for filing with the Secretary of State in accordance with the provisions of the General Laws of Rhode 1sland, 1956, as amended, Chapter 42-35, specifically Section 42-17.3-2 and the Public Laws of Rhode Island, 1978, Chapter 229 and Chapter 46-2.

Attest a true copy.

ERVIRONMENTAL STANDARDS BOARD

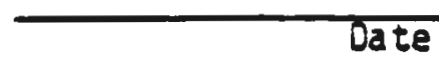

H. Denman Scott, M.D.

Director of Health
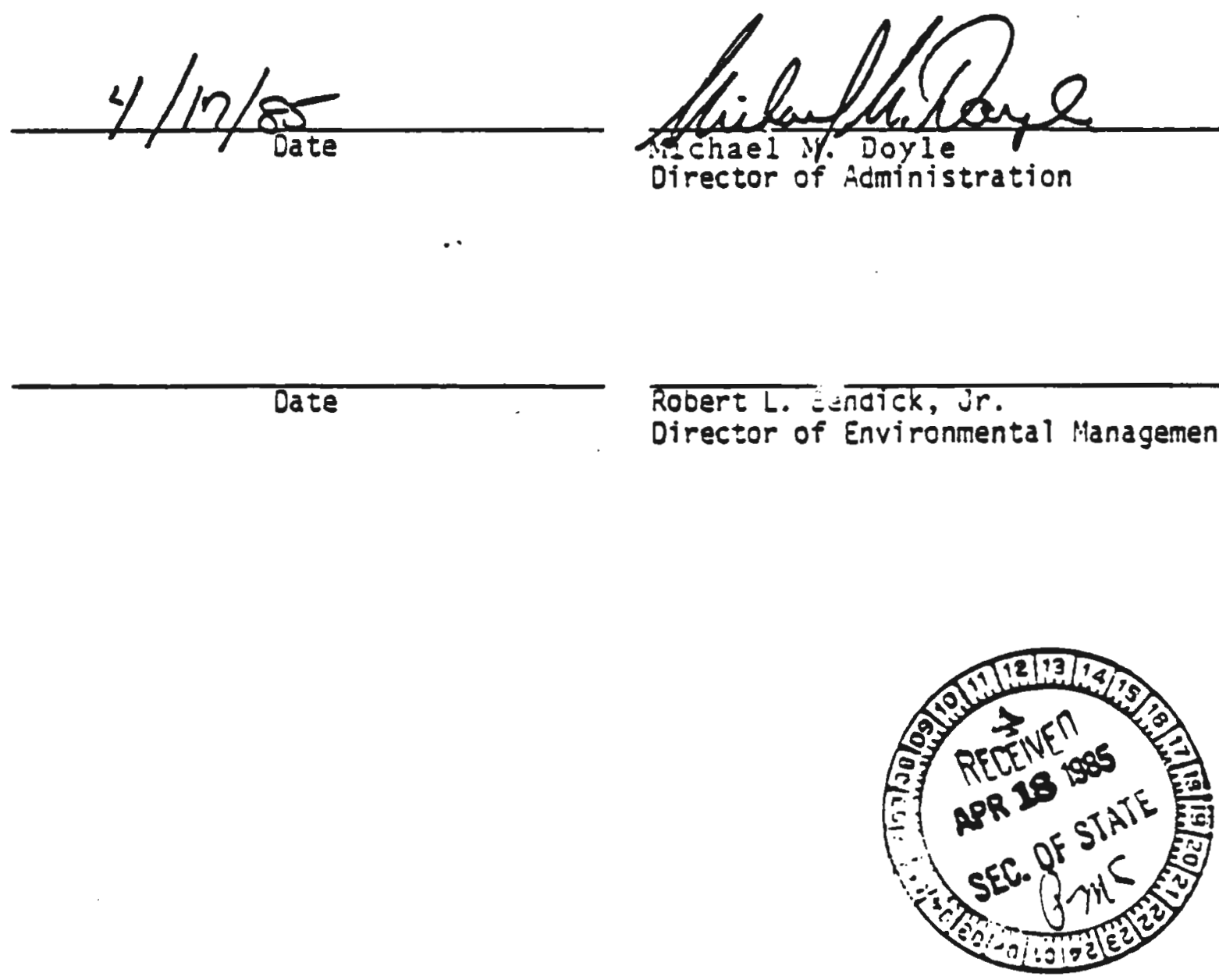
Eazazdous substance, as deflned by section $101(14)$ of CERCuA, means (a) any substance desigrated pursuant to section $311(b)(2)(A)$ of the Cis (see List 1); (b) any element, compound, mixture, solution, or substance desigrated pursuant to section 102 of CERCLA (see List 2), (c) any hazardous waste having the characteristics 1dentified under or listed pursuant to section 3001 of the Solld Waste Disposal Act (but not including any waste the regulation of which under the Sol1d Waste Disposal Act bas been suspended by Act of Congress): (d) any toxic pollutant listed under section 307 (a) of the CHA (see List 3); (a) any hazazdous aif pollutant listed under section 112 of the cleas Afs Act (see List 4), and (f) any tminently hazardous chemical substance of mixture with respect to which the Administrator of EPA has taken action pursuant to section 7 of the Ioxic Substances Control Act (see Llst 5). The terma do not include petroleum, including crude ofl or any fraction thereof which is not otberwise specifically listed or designated as a hazardous substance under subparagraphs (a) through (t) of this paragraph, and the term does not lnclude natural gas, natural gas ilquids,. ligulfied natural gas or synthetic gas usable for fuel lor mixtures of natural gas and such syntbetic gas). 


- bisT:

Hazardous Substances - Clean Hater Act Section 102

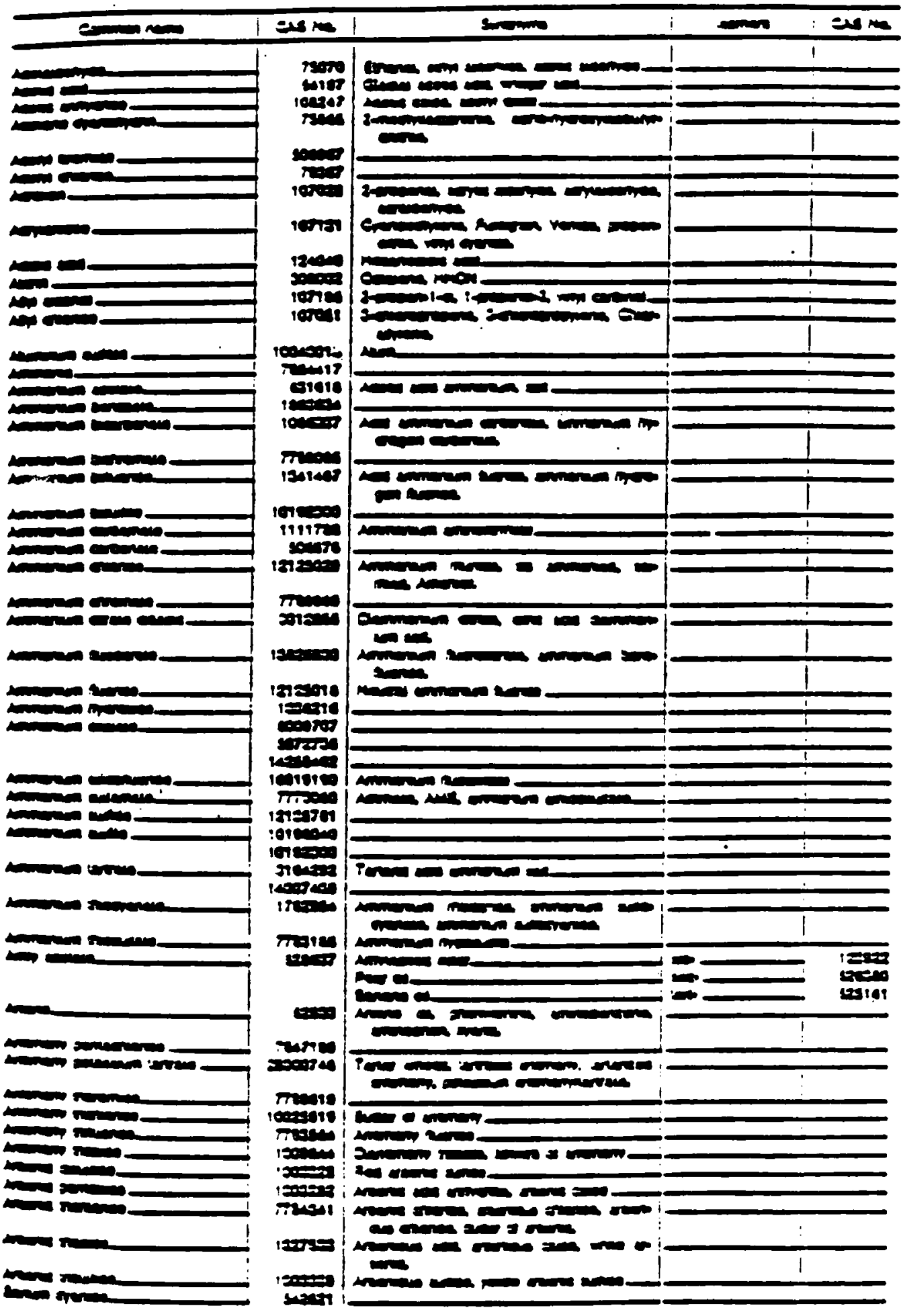




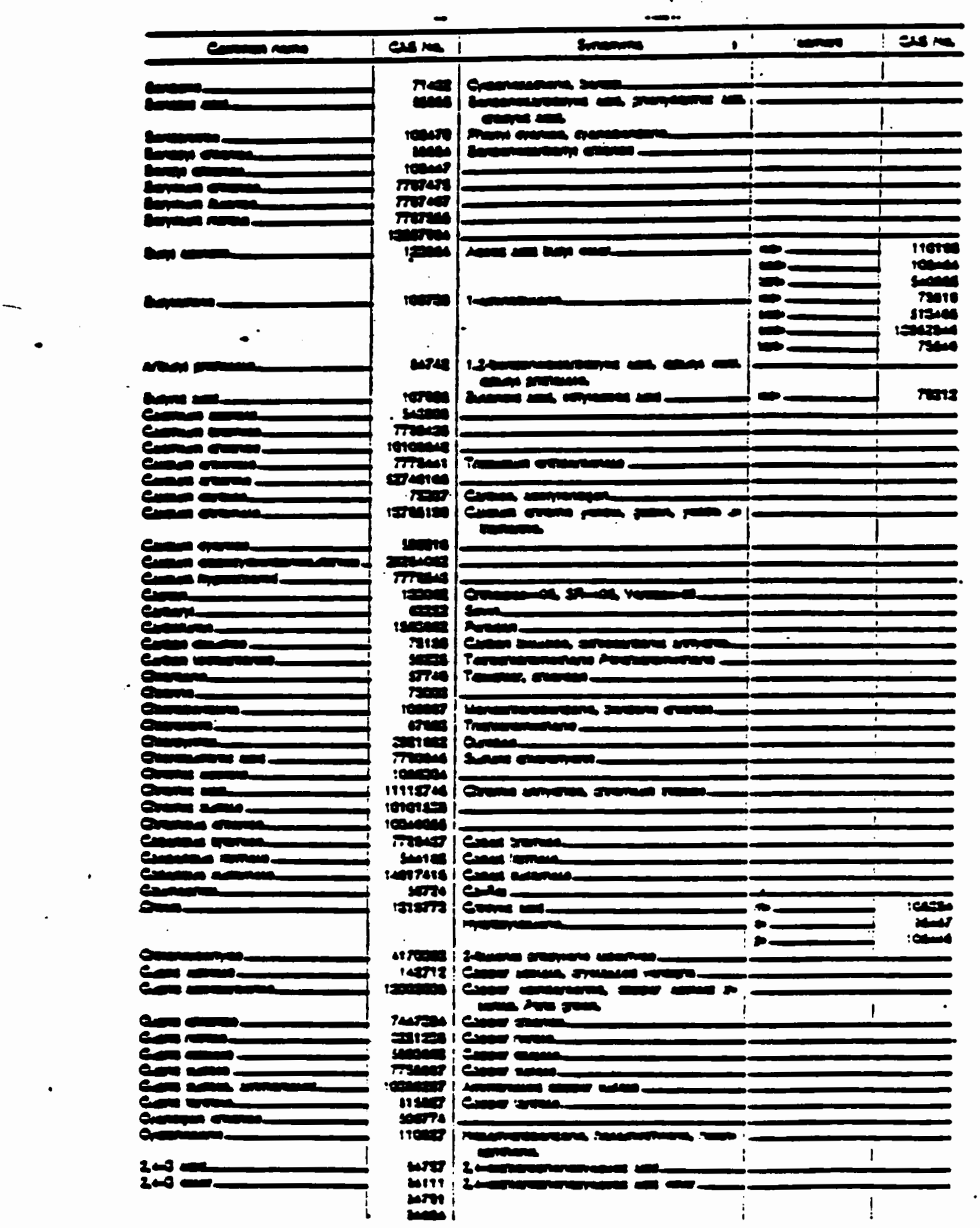




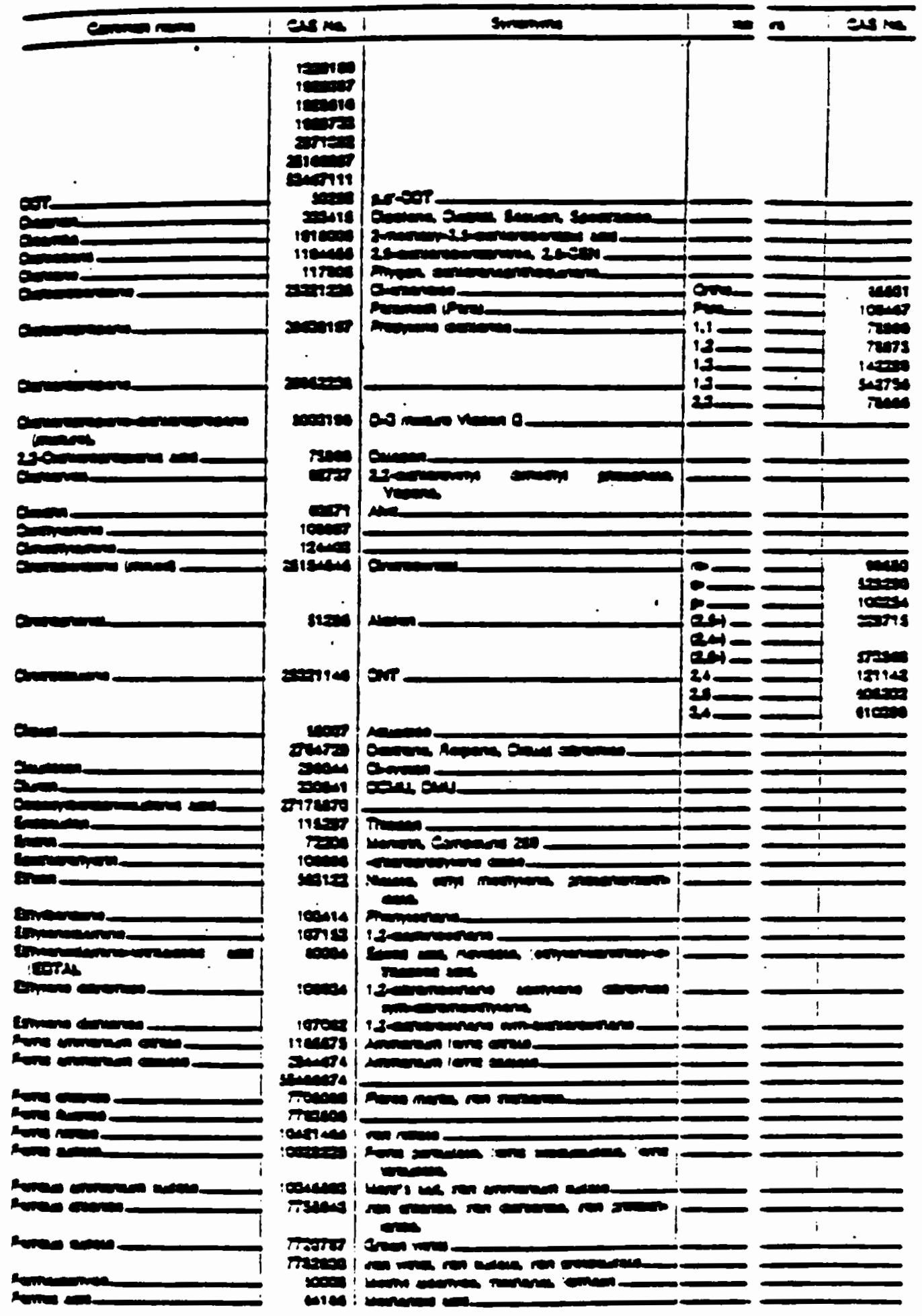




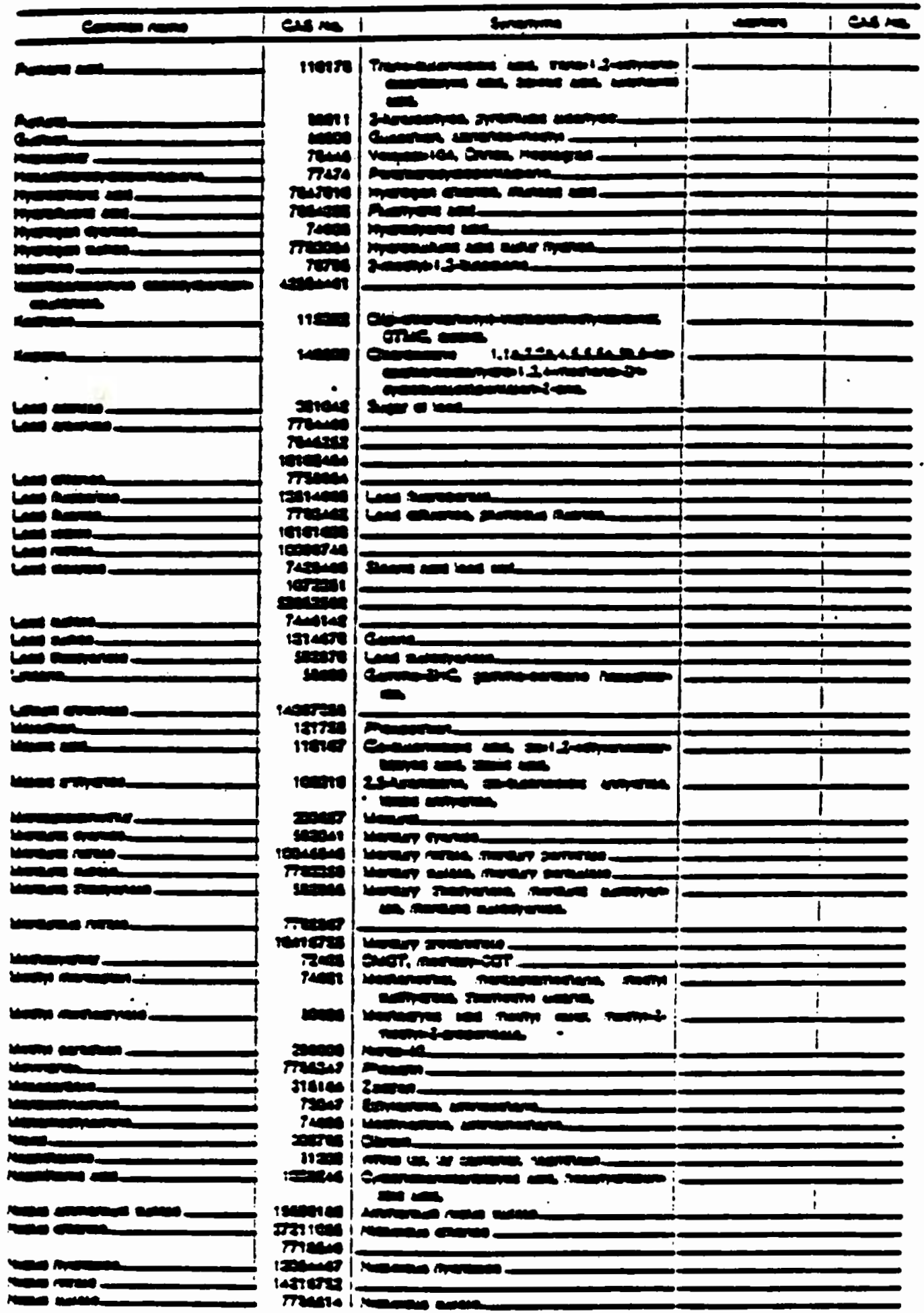




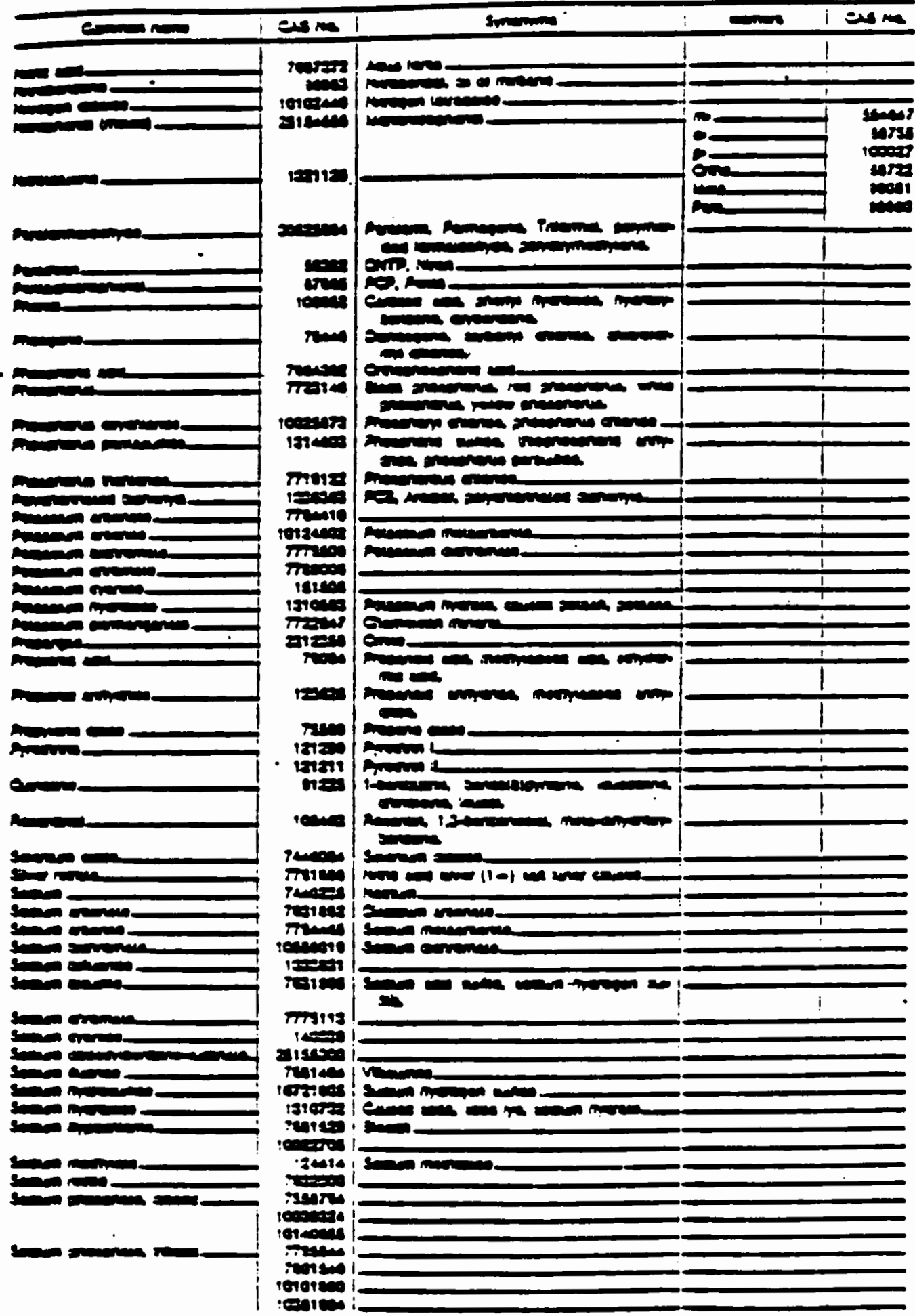




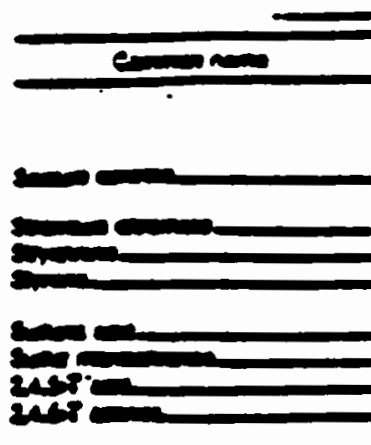

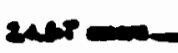

$20 \times 10$

it

2A숭

Prom

Penm nom

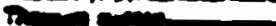

rom

Prum

Prom

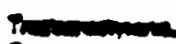

Prumand in

70

Phementom

Unim ram

U⿴囗十)

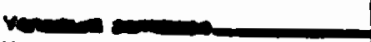

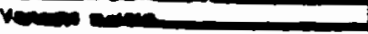

Kim

nim

$2 \sin$

2

5

20

20

en mas

ens

i

(1)

l 1 ens

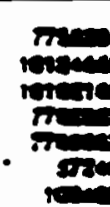

Then

eininge

$\because$

and

Cramenom

ictom

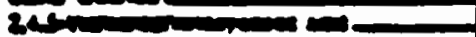

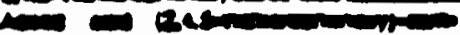

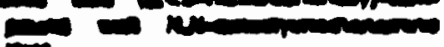
(in,

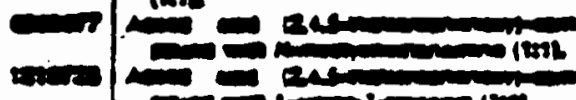

enine

40 ackins

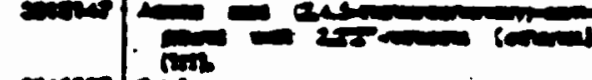

Sim

aris

innaty

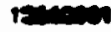

-

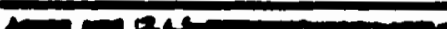

$\rightarrow$

r.n

ing

sem

n.

r.Pen

romen

rensieg

-0

$i \frac{1}{i}$

$+\infty \sin ^{2}$

thes rom $\mathrm{T}$

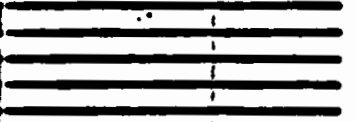

10.0.

Ne:

$\sin$

S.n.

arcion

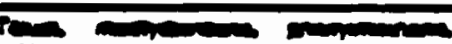
ing

enm

$-\frac{1}{1}$

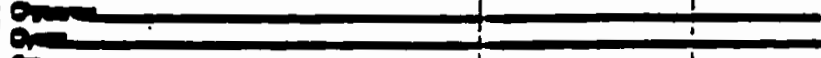

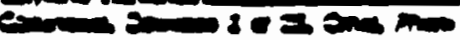
(2)

exts

Trus

$7 \cdot 3$

1 sen

revain

aring

istenter

errats.

10

$r=: 5$

$1+-\cdots$

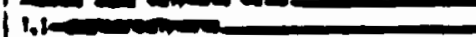

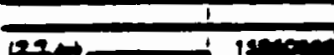

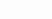

eres

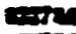

C21 - ont

OAll

Ren

Ener ane

1e.in !

(1)

ising

14rexin

ner.

2......

$2=0$

inens

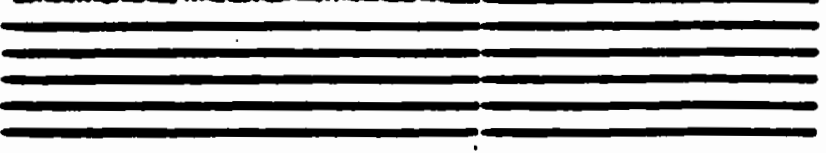




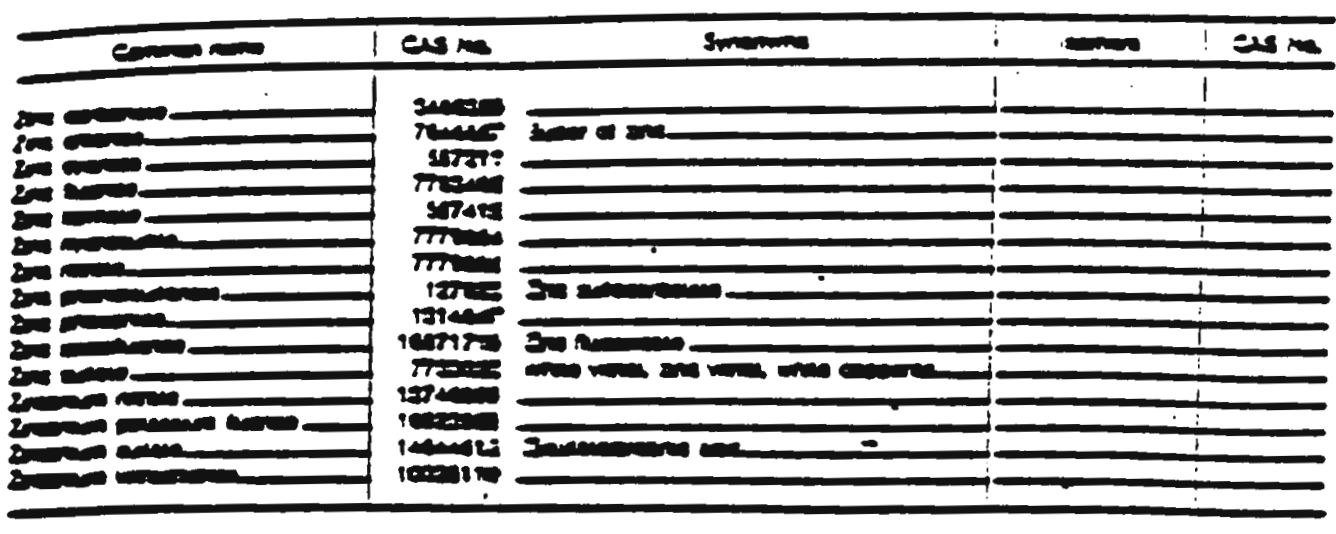


List 2

88

CERCIA Section 102 Wastes (as of February 1985)

None to Date. 
- i.l jiesloroernane

$\therefore$ i jiealoreesnyleme

$1,1,1$ irsesdoroptrase

1,1.2 Prienlopoernaee

1,1.2.2 Potracaloroermane

1.2 Dieslarouenzeno

1.2 otealorgertane

1.2 Oseslar sor opanes

1,2 Osanomplimwrastas

1.2 iras -atealoreotavl ane

1.2. + Prtendepatenzeme

1,9 olestlepebenzene

1.3 Olealoreoroosylase

$1,+$ Otenloreochzeme

2 Alorenaghtbadone

2 Calaroshamed

2 Mitrosanel

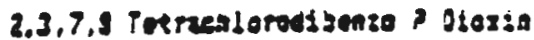

2.4 odemlarsanomel

$3 .+$ osconerylabenel

2.t Olaitromened

2.4 Oinitrotelume

2.4.6 Trienler venemol

2.6 Dinitsotelume 2-Elarontmyluiay! Etaper

3.3 ojes lapouenzidiso

3.t Jemzof Juerzathome

- Iresconemel Phemyl Ether

- Dlarabnamel phemyl ildier

- Hitroenemed

$4, t^{\prime} 000$

$4,4^{\circ}$ got

$6,4^{\circ} 20 T^{\circ}$

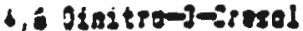

temsenthene

teanzenthylene

teast ara

terylan:!:::.

Alde:a

Alana-anc

Hlgas-insegulian

insispeste

thesmeny, ierad

trsanse. iotal

Jonzeno

Jent: sine

3mzo (d) duthpaesne

jenze (a) Byrene

Jenzs (qqui) Jorviene

3enzo (i) :-:jeranthene

Japes:

je:s-juthe

3era-seos:! : in

Jis (2 Jiargernoxy) 4o:nane

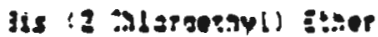

Jis i: Diopazssopsoubl at:er

Jis : I E.svihorv!) in:ma!ats

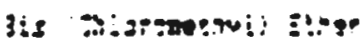

ipsootisp

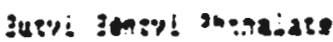

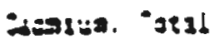

eants - ilean date
Eargen iotracsiar:ae

Olarosene

Cisloreoenzme

Oloredibromosthano

Enloreetinate

Clapoforn

Qironzen. iotal

Cryseno

Coner, Total

Evandie. Total

Dolta-duc

O1-7intyl Puesalate

01-H-Detyl Phtradate

Oblemze $(2, i)$ Mathraesmo

Olenlorgar onometrine

olealoreat fluoreantiase

Otelarta

Ssetoyl intiadate

OLentayl Phthalats

Eodesalfa inffats

Eotrita

Codida Aldemyte

Itivisenzmo

Dreorathene

Fuarme

Seme-iks

Hoptrender

Hoptzealor loozds do

Hersect lereech ame

Horach lep secutadi ene

Horcenloporyeleoentadteme

Herrealap sethane

Laseme $(1,2.3$ ed) Pyrme

iseonarene

Lext. Total

mperery, iotal

Hetrayl Irando

Motayl alorsde

merevlene Coloride

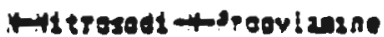

Hitrasodisetsylanse

Wis pesedianenyl anshe

menthatome

Mered, ietal

Wt tevent mo

2allor or-sissol

20p-1016

다-1니

193-12:5

$x-1242$

$963-1249$

res-1754

$?=3-1350$

Penrzes larsans.rod

Jumenesterme

thonol

stromols, ieral

ropene

Selensur. "3ra:

ji:ver. "oral

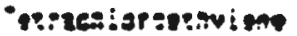

nablize. iotal

ialuene

iesanneme

irseslargetsyigene

Pricalopof tuarano:.9ane

Hanyl CMlar:se

Isae, iatad 
Bazardous Ais Pollutants Clean Aif Act -

CAA Secticn 112 (as of Februafy 1985)

\author{
Arsenic \\ Asbestos \\ Benzere \\ Beryl1ium \\ Coke Oren Emissions \\ Mercury \\ Vinyl Chloride
}




\author{
DEPARTMENT OF ENVIRONMENTAL MANAGEMENT \\ STATE OF RHODE ISLAND AND PROVIDENCE PLANTATIONS
}

\author{
UNDERGROUND STORAGE TANK \\ REPLACEMENT REVOLVING LOAN FUND
}

RULES AND REGULATIONS

\author{
DRAFT \\ March; 1987
}

AUTHORITY: Regulations adopted pursuant to Chapters 46-12 and 42-35 of the General Laws of Rhode Island of 1956, as amended. 
TABLE OF CONTENTS

Section

Title

page

1.00

AUTHORITY

1

2.00

PURPOSE

1

3.00

SEVERABILITY

1

4.00

DEFINITIONS

1

5.00

ELIGIBILITY OF ACTIVITIES AND REQUIREMENTS

3

6.00

APPLICATION PROCEDURES AND REQUIREMENTS

4

7.00

TERMS AND CONDITIONS

8

8.00

REIMBURSEMENT PROCEDURES

9

9.00

AVAILABILITY OF FUNDS

10

10.00

ADOPTION AND FILING

11 
1.00 AUTHORITY - These regulations are adopted pursuant to Chapter 486 of the Public Laws of Rhode Island of 1985 and Chapters 46-12 and 42-35 of the General Laws of Rhode Island of 1956, as amended.

2.00 PURPOSE - The purpose of these regulations is to implement the provisions of Chapter 46-12 pertaining to the Underground Storage Tank Replacement Loan Fund. The goal of the loans is to provide low interest funding to replace existing underground storage tanks that may pose a danger to public health.

3.00 SEVERABILITY - If any provision of these regulations or the application thereof to any individual or circumstance is held invalid by a court of competent jurisdiction, the remainder of the regulations shall not be effected thereby. The invalidity of any section or sections shall not affect the validity of the remainder of these regulations.

4.00 DEFINITIONS - Unless the context specifically indicates otherwise, the meaning of terms used in these rules shall be as follows:

4.100 COMMERCIAL - means all non-private facilities.

4.101 FACILITY - means all contiguous land, structures, facility components and other appurtenances that form a district geographic unit and at which petroleum products or hazardous materials are stored in underground storage tanks. 
4.102 HAZARDOUS MATERIALS - means any material defined as a "hazardous substance" by section $101(14)$ of the Comprehensive Environmental Response, Compensation, and Liability Act of 1980 (42 USC 9605), as amended (see Appendix A). Hazardous materials shall also include any material defined as a "hazardous waste" pursuant to the Rhode Island Hazardous Waste Management Act of 1978, as well as any of the following materials:

-Acetone

-Ethanol

-Ethylene oxide

-Methanol

-Methylene Chloride

-Perchloroethylene

4.103 PETROLEUM PRODUCT - includes:

-Gasoline

-Fuel oil (No.1)

-Diesel Oil (No.1-D and 2-D)

-Waste oil

-Gasohol

4.104 PRECISION TEST - means a test able to determine whether or not an underground storage tank is leaking as defined by NFPA 329, "Underground Leakage of Flammable and Combustible Liquids". This test must be capable of accurately detecting a tank or piping leak 
as small as 0.05 gallons per hour, adjusted for all variables. The test method must be approved by the DIRECTOR prior to use, and must be conducted by persons who have demonstrated capability to properly conduct the test as determined by the DIRECTOR.

4.105 PRIVATE - means farm or residential underground storage tanks holding less than 1,100 gallons and storing motor fuel or heating oil for non-commercial purposes.

4.106 REPLACEMENT - means installation of new underground storage tank or tanks.

4.107 UNDERGROUND - means 108 or more of the volume of facility components (storage tanks and piping) is buried in the ground.

4.108 UNDERGROUND STORAGE TANK - means any one or combination of tanks (including underground pipes connected theretol which is used to contain an accumulation of petroleum products or hazardous materials, and the volume of which (including the volume of the underground pipes connected theretol is 108 or more beneath the surface of the ground.

5.00 ELIGIBILITY OF ACTIVITIES AND RECIPIENTS

5.01 ELIGIBLE COSTS AND ACTIVITIES

Costs of replacement including design, engineering, construction, parts and construction supervision. 
5.021 Applicant must provide evidence that he/she is the owner of the property where the underground storage tanks are located or that he/she has a long term lease equal to the duration of the loan.

5.022 Applicant must provide evidence that he/she is credit worthy.

5.023 In cases of joint, corporate or company ownership the loan application must be signed by an individual with the power to bind the corporation, company or partnership.

\subsection{APPLICATION PROCEDURES \& REQUIREMENTS}

6.100 FORMS - Applications must be submitted on forms provided by the Rhode Island Department of Environmental Management. Applications will at a minimum contain the following information.:

6.101 The name of owner of the business which owns the underground storage tank and the name of the owner of the property at which the tank is located. The nature of the ownership, i.e., sole proprietorship, partnership, corporation or other.

6.102 Address of the property for which the loan is sought and its plat and lot number.

6.103 Certified copy of the deed or the lease for the property. 
6.104 Names of all mortgage or lien holders and the original and outstanding balance of the mortgage liens.

6.200 CREDIT WORTHINESS - Applications must contain such additional information as is necessary to establish credit worthiness. Such information will be held in confidence. Information required may include but will not necessarily be limited to:

6.201 Income data including taxable yearly income and/or weekly income from all sources of the business.

6.202 Asset data including value of equipment and property or real estate.

6.203 Debt data including amounts owed on all loans, mortgages or rent payments.

6.204 Amount of the loan sought, substantiated by submission of three bids to be obtained from duly licensed engineers or contractors.

6.300 APPLICATION REVIEW PROCEDURES

6.301 Applications for loans to repair or replace underground storage tanks will be reviewed and awards made by the Department of Environmental Management pursuant to the criteria and procedures set forth in these rules and regulations. 
$6.400 \cdot$ APPLICATION REVIEW CRITERIA

The following basic criteria shall be applied in reviewing loans.

6.401 Availability of funds.

6.402 Completeness of application including required documents; incomplete applications will be returned.

6.403 Accuracy of information - untrue or misleading representations may be grounds for rejection.

6.500 CRITERIA FOR ESTABLISHING PRIORITIES

In the event that the department receives more requests for loans than it has funds available it will award loans first to those eligible applicants that have the highest score as determined according to the following criteria.

6.501 ADJACENT LAND USE

\section{SCORE}

I Wells in general. use in area:

a. public water supply wells 5

b. private wells 3

II Density of residential development:

Heavy 3

Moderate $\quad 2$

Sparse 1

Subtotal 
II Special consideration facilities:

a hospital/clinic 3

b. convalescent/nursing home 2

c. school 1

Subtotal

6.502 Type of Facility:

I Retail Gasoline 5

II Wholesale Gasoline 5

III (Light Fraction)

Hazardous Materials 5

\section{SCORE}

Farm/Residential Gasoline 2

Heating oil Commercial 3

Heating Oil Residential 2

Other Commercial 1

Subtotal

6.503 Characteristics of Tank

Leaking 5

Steel Construction 3

Other Material -

Age 10-25 years 4

Subtotal

Multiply this by number of tanks

6.504 Ownership Characteristics:

Small Rusiness 5

Chain Affiliate 3 
Major Affiliate

Private Residential

Corporate Hazardous

Materials

Subtotal

6.505 Total Priority Score

Total of Subtotals in

- Sections 6.501 through 6.504

\subsection{AWARDS}

6.601 The Rhode Island Department of Environmental Management shall notify the applicants of the award or denial of a loan application within sixty (60) days of receipt of a complete application.

6.602 The amount of the loan shall not exceed the lowest of the three bids submitted by the applicant pursuant to section 6.204 above.

6.603 Notice of award shall set forth all loan terms, conditions and schedules.

6.604 Notice shall be by registered mail.

$7.00 \quad$ TERMS AND CONDITIONS

7.100 TERMS AND CONDITIONS

7.101 Award of a loan shall become a debt of the applicant secured by enough collateral to satisfy the amount of the loan. 
7.102 The loan award will set forth the repayment schedule and term at an interest rate determined according to section 7.200 below.

7.103 The entire balance of the loan shall become due and payable if the business is sold or otherwise conveyed and/or if the applicant fails to complete the work for which the loan was made.

7.104 An applicant may decline to accept 1008 of the loan award, in which case the repayment schedule and term may be recomputed.

7.105 Any loan awarded under these rules may be paid up in whole or in part at any time without penalty.

7.200 RATES AND TERMS

7.201 Loan rates shall be fixed by the Department of Administration at two (2) points below the six month Treasury Bill rate as certified by the General Treasurer at the time the loan is awarded. 7.202 Rates will remain fixed during the term of the loan.

8.00 REIMBURSEMENT PROCEDURES

8.100 Loan funds for engineering or design will be released upon receipt of the Department of Environmental Management of a copy of the engineer's bill and approval of the design by the Division of water Resources. 
8.101 Loan funds for parts and materials will be released upon receipt by the Department of Environmental Management of a copy of the invoice from the manufacturer or distributor.

8.102 Loan funds for the construction of the repair or replacement will be released upon receipt by the Department of Environmental Management of a copy of the contractor's bill and a certificate of compliance issued at the completion of the project by the Division of Water Resources noting that the repair or replacement of the tanks was carried out according to the underground storage tank regulations adopted pursuant to Chapter 46-12 of the General Laws of Rhode Island.

8.20 FORM AND AMOUNT OF PAYMENT - Payment will be by Invoice Voucher drawn against the state of Rhode Island and shall be jointly payable to the applicant and his/her contractor in an amount equal to the contractor's itemized bill.

\subsection{AVAILABILITY OF FUNDS}

9.100 At or near the beginning of each fiscal year the Director of the Department of Environmental Management shall determine the amount of money which shall be made available and the application period for loans during that year; said funds to be appropriated from those then currently 
available in the Underground Storage Tank Replacement Revolving Loan Fund.

$10.00 \quad$ ADOPTION AND FILING

The foregoing rules and regulations, after due notice and hearing, are hereby adopted and filed with the secretary of state this day of

1987, to become effective twenty (20) days thereafter, in accordance with the provisions of Chapter 42-44.1, 42-17.7 and 42-35 of the General Laws of Rhode Island, 1956, as amended.

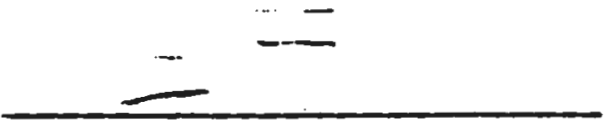

Robert I. Bendick, Jr.

Director

Department of Environmental

Management

0273A 
FOOTNOTES

1. New England Interstate Water Pollution Control Commission, Here Lies the Problem... Leaking Underground Storage Tanks. Boston, January, 1985. p. 3.

2. United States Environmental Protection Agency Office of Solid Waste, Summary of State Reports on Releases from Underground Storage Tanks. Washington, October, 1984. p. 14 .

3. Stanley, Gerald F. A.U.S.T.--A Billion Dollar Time Bomb for Fleet Operators, Commercial Carrier Journal. March, 1987. p. 9.

4. United States Environmental Protection Agency, Office of Underground Storage Tanks, What's in the Pipeline \#26A. April, 1987. p. 2.

5. Susan Redlich, The Community Tank Census; Managing the Risks of Underground Storage. Nashua Regional Planning Commission. Nashua, 1986. p. I-3.

6. Ibid, P. I-4.

7. Ibid.

8. Ibid.

9. United States Environmental Protection Agency, Office of underground Storage Tanks, Proposed Regulations for Underground Storage Tanks: Your Financial Responsibilities. Washington, April, 1987. p. 3. 
10. United States Environmental Protection Agency, Office of Underground Storage Tanks, The Trust Fund for Leaking Underground Storage Tanks. Washington, March, 1987. p. 1 .

11. Ibid. p. 2 .

12. Rhode Island Department of Environmental Management, Regulations for Underground Storage Facilities Used for Petroleum and Hazardous Materials. Providence, April, 1985.

13. Ibid. p. 10 .

14. Personal Interview, Sue Kiernan, senior Environmental

Planner, Rhode Island Department of Environmental

Management, Groundwater Protection Division, November, 1987.

15. Ibid. 


\section{BIBLIOGRAPHY}

Cross, Richard. Billion Dollar Time Bomb for Trucking:

Leaking Underground Storage Tanks. Commercial Carrier Journal. March, 1987.

- "This Stick Can cost You Millions." Commercial Carrier Journal. November, 1986.

Nashua Regional Planning Commission. A Practical Guide to Groundwater Resources and Their Protection. Nashua, June, 1986 .

New England Interstate Water Pollution Control Commission. Here Lies the Problem... Leaking Underground Storage Tanks. Boston, January, 1985.

Pisanelli, Anthony, and Bridge, Jenny. Overview of Regulatory and Non Regulatory Techniques for Local Groundwater Protection. NEIWPCC, Boston, November, 1986. Nashua Regional Planning Commission. The Community Tank Census; Managing the Risks of Underground Storage. Susan Redlich, ed., 1986.

Rhode Island Department of Environmental Management. Underground Storage Tank Replacement Revolving Loan Fund. March, 1987.

Stanley, Gerard F. LUST--A Billion Dollar Time Bomb for Fleet Operators. Commercial Carrier Journal. March, 1987. 
U.S. Government Printing Office. Federal Register.

April, 1987. Vol. 32, No. 4.

United States Environmental Protection Agency Office of

Solid Waste. Summary of State Reports on Releases

from Underground Storage Tanks. Washington, October, 1984 .

United States Environmental Protection Agency, Office of

Underground Storage Tanks. What's in the Pipeline.

\#26A, April, 1987.

- Proposed Regulations for Underground Storage

Tanks: Your Financial Responsibilities. Washington, April, 1987. 